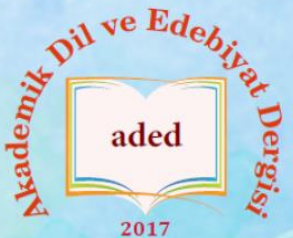

e-ISSN: 2618-6349
Akademik Dil ve Edebiyat Dergisi

Academic Journal of Language and Literature

Cilt/Volume: 3, Sayı/Issue: 4, (Aralık/December 2019)

USTALARA SAYGI-I:

Prof. Dr. Fatma Sabiha KUTLAR OĞUZ'a Armağan

\title{
Hıfzî Ağa’nın (ö. 1173/1759-60) I. Mahmûd İçin Yazılan Şiirler Mecmûası (TSMK-Revan 1977) Üzerine
}

\section{On the Hıfzì Ag̀a's (d. 1173/1759-60) Macmū'a/Miscellany - a Collection of Poems Written for Mahmūd I. (TSMK-Revan 1977)}

\section{Hatice AYNUR*, F. Meliha ŞEN**}

Prof. Dr., İstanbul Şehir Üniversitesi

\section{Öz}

Dr., Araștırmacı

e-mail ${ }^{\star}$ : haticeaynur@sehir.edu.tr

e-mail ${ }^{* *}$ : ftmsen@yahoo.com

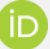

https://orcid.org/0000-0002-1489-379X

\section{Araştırma Makalesi/Research Article}

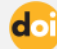

https://doi.org/10.34083/akaded.653182

\section{Sorumlu Yazar/Corresponding Author}

Hatice Aynur, İstanbul Şehir

Üniversitesi, İstanbul/Türkiye

Geliş Tarihi/Received : 29.11.2019

Kabul Tarihi/Accepted: 18.12.2019

\section{Atıf/Citation}

AYNUR, Hatice, SEN, F. Meliha (2019)

Hıfzî Ağa’nın (ö. 1173/1759-60) I.

Mahmûd İçin Yazılan Şiirler Mecmûası (TSMK-Revan 1977) Üzerine. Akademik Dil ve Edebiyat Dergisi, 3 (4), 39-73.

DOI: $10.34083 /$ akaded.653182
Mecmûa çeșitli konu ve türdeki eserlerin kaydedilmesiyle meydana getirilmiş derlemedir. Edebî metinlerin toplandığı mecmûalar son zamanlarda klaâsik Türk edebiyatı araștırmacılarının yoğun çalıștığı yeni bir saha hâline gelmiștir. Mecmûalar derleyen(ler)inin edebî zevkini ve ait olduğg muhiti yansıtması bakımından önemli kaynaklardır, fakat genellikle mecmûaların derleyen(ler)ini ve tertip edildikleri tarihi tespit etmek kolay değgildir. Topkapı Sarayı Müzesi Kütüphanesínde (Revan 1977) bulunan ve Hıfzi Ağa (ö. 1173/1759-60) tarafından 1143-1144 (1730-32) tarihleri arasında derlenen bir mecmûa I. Mahmûd döneminin (1730-1754) edebî ve siyasî tarihi hakkında önemli bir kaynak olması bakımından dikkat çekicidir.

Zamanının tanımıș hat üstatlarından meșk etmiş olan Hıfzî, I. Mahmûd'un sır kâtibi olarak Topkapı Sarayı́nda bulunduğu zamanlarda derlediği Mecmûa’sını iki kısma ayırmıștır. Birinci bölümde kendisinin de dâhil olduğu șairlerin șiirlerini bir araya getirmiștir. I. Mahmûd'un doğumu, derse bașlaması, sakal bırakması, tahta çıkması, 1144 (1731) senesinin gelmesi ve padișah hakkında yazılmıș çeșitli șiirlerden meydana gelen birinci kısımda 53 değișik șairin șiirlerine yer verilmiștir. Bu șiirlerin çoğunluğu Sultan'in tahta çıkıșı için yazılmış târîh manzumeleridir. Mecmûa 'nın ikinci kısmında Hıfzî̀ nin yazdığı ve türünün ilk örneği kabul edilen mensur Rûznâme metni bulunmaktadır. III. Ahmed'in (salt. 17031730) tahttan indiriliși ile I. Mahmûd'un padișah olması sırasında İstanbul'da meydana gelen olaylar hakkında gün gün bilgi veren bu eser Patrona Halil İsyanı (1730) ile ilgili birinci elden kaynak olması bakımından önemlidir.

İki bölüme ayrılan bu makalede Mecmûánın manzum olan birinci kısmı incelenecektir. Mecmûánın bir yazma eser olarak tanıtımı yapıldıktan sonra Hıfzî Ağa ́nın mürettip ve yazar kimliği üzerinde durulacaktır. Hıfzî, șiirleri altı kısma ayırmıștır. Bu tasnifin ve șiirlerin incelenmesinden sonra șairler hakkında mevcut bilgiler verilecektir. Makalenin ikinci kısmında MESTAP projesine göre Mecmûa'daki șïlerin listesi ve dökümü yapilacaktır.

Anahtar Kelimeler: I. Mahmûd, Hıfzî Ağa, klasik Türk edebiyatı, târîh manzumesi, mecmûa, rûznâme.

* Bu Mecmûa'ya ulaşmamız konusunda yardımları için meslektaşımız Ramazan Ekinci'ye teşekkür ederiz. 


\title{
On the Hı́fzì Aġa's (d. 173/1759-60) Macmū'a/Miscellany-a Collection of Poems Written for Maḥmūd I. (TSMK-Revan 1977)
}

\begin{abstract}
Mecmū 'a/Miscellany comprises a collection of texts of various themes and genres, of which the literary ones have yielded a new and rich field of study recently for researchers in classical Turkish literature. Mecmū 'as are important sources of reflection on literary appreciation in collector circles, although it is difficult generally to ascertain the identity of those collectors and the date of registration. One particular Mecmū 'a, which is located in the Library of Topkapı Palaca Museum (Revan 1977), collected by Hif̧̄i A $\dot{g} a$ (ö. 1173/1759-60) between 1143-1144 (1730-32), is a remarkable source of insight into literary and political history during the beginning and early part of the reign of Mahmūd I (1730-1754).

Hifzì, who was a student of the masters of calligraphy of the time, collected his Mecmū' a as two parts when he was privy secretary to Mahmūd I. In the first, he gathered poems of various poets including himself, the material consisting of poems written by 53 poets on different subjects such as birth of Mahmūd I, beginning education, growing a beard, accession, the arrival of new year (1144/1731) and various verses. Indeed, most are chronograms written for the new sultan's accession. There is also a Rüznäme in the second part of the Mecmū 'a, which is accepted as the first example of that genre by Hifzil. This text records incidents that occured in Istanbul during the dethronement of A hmad III and the subsequent accession of Mahmmüd I, and is significant as a primary source.
\end{abstract}

This paper comprises two parts, the focus of the first being on the first section of the Mecmū 'a. It acquaints the reader with the Mecmū' a as a manuscript and then introduces Hufżi as a collector and an author. Hifẓi subdivided poems into six parts, and so, after consideration of such subdivisions and analysis of his poems, this paper presents the data that is available currently about the poets in question. The second part of this article presents the content of the Mecmü' $a$ in accordance with the MESTAP project.

Key words: history, $18^{\text {th }}$ century, Maḥmūd I, rūznāme, classical Turkish literature, poetry, macmū 'a/miscellany. 


\section{Giriș}

Özellikle 2000'li yıllardan itibaren araştırma nesnesine dönüşerek muteber bir çalışma sahası olarak öne çıkan mecmûa metinleri, değişik muhtevalı metinlerin biraraya getirilmesiyle meydana gelen derlemelerdir. ${ }^{1} \mathrm{Bu}$ yazıda 1143-1144 (1730-32) yılları arasında Hıfzî Ağa / Hıfzî Mehmed Efendi (ö. 1173/1759-60) tarafından tertip edilen ve Topkapı Sarayı Müzesi Kütüphanesi'nde (Revan 1977) bulunan Mecmûa'nın manzum kısmının incelenmesi amaçlanmaktadır. Mecmûa'nın önce biçim ve içerik tanıtımı yapılıp derleyen hakkında bilgi sunulmasının ardından şiirlerin MESTAP projesine göre dökümüne yer verilecektir.

\section{Mecmûanın Biçimsel Özellikleri ve Düzeni}

Mecmûa'nın fiziksel tavsifi: Aharlı kâğıt. 220X165 mm. 68 yk. Talîk³, 19 satır. Serlevhalar müzehhep, cetveller yaldızlı. Şemse ve köşelikli kahve deri cilt.

Dış kapağın iç yüzünde: (eski harfle) 1977, altta Revan; üstte 233/35279 (Arap harfli ve kırmızı mürekkeple) Topkapı Sarayı Tahrîr Komisyonu (ka-

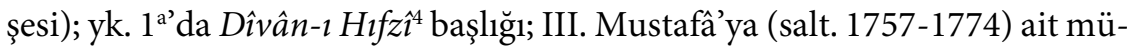
hür: Elhamdü lillâhi'llezi hedânâ li-hazâ ve mâ künnâ li-nehtediye lev lâ en

\footnotetext{
${ }^{1}$ Osmanlı döneminde kaleme alınmış/tertip edilmiş eserler arasında mecmûaların araştırma nesnesine dönüşümünün dinamikleri ile bu sayede ortaya çıkan çalışmaların niteliği ve niceliğinin irdelenmesinin ayrı bir çalışma konusu olduğunu belirtmek isteriz. Bu konuda, Mecmûa: Osmanlı Edebiyatının Kırkambarı (2012) adlı kitabı kapsamı, içerdiği bilgi ve değerlendirme açısından Osmanlı sahasındaki mecmûalar üzerine ilk ve öncü çalışma olması; Fatih Köksal'ın öncülüğünde yürütülen MESTAP projesini (https://mestap.com) ise konuyla ilgili güncel çalışmaların merkezi olması bakımından zikretmek gerekir. MESTAP projesinin websitesinden ve www.osmanliedebiyati.com sitesinden mecmûa üzerine yapılmış çalışmalara ulaşmak kolaylıkla mümkün olduğu için tekrara düşmemek için burada bu konudaki eserlerin dökümünü vermekten kaçınılmıştır.

2 Daha sonra işaret edileceği üzere Hıfzî Mecmûa'yı tertip ettiği sırada Topkapı Sarayı'nda görevli olduğu için Hıfzî Ağa olarak tanınmaktaydı. Bundan dolayı yazıda Mecmûa'nın geçtiği yerlerde Hıfzî Ağa'nın kullanılması tercih edilmiştir.

${ }^{3}$ Büyük ihtimalle Hıfzî̀nin elyazısı olduğunu düşünebiliriz, yapılacak başka incelemelerle kesinleştirilmesi söz konusu olabilecektir.

${ }^{4} \mathrm{Bu}$ başlığı veren kişinin Mecmûa'yı incelemediği ve şiirleri görünce bunların Hıfzî Ağa'nın kendi şiirleri olduğunu zannetiğini söyleyebiliriz.
} 
hedânâllâh vakf-ı Mustafâ Şâh bin Ahmed Hân Sâlis el-muzaffer dâimâ, ${ }^{6}$ Altta TKS. Müzesi Revan Sa: 1977 kaşesi; Kit'a der vasf-ı tuğrâ-yı garrâ-yı Sultân başliklı iki beyitlik manzume (Habbezâ tuğra-yı cihândârâ ki anın/ Cilvegâhı bahr u ber ins ü per fermânberi // Râm ederse emrine dünyâyı sertâ-ser nola/ Hırz edinmiş nâm-ı sultân-ı adâlet-güsteri).

Mecmûa'da yk. $1^{\mathrm{b}}-37^{\mathrm{a}}$ arası ve devamında bazı yaprakların kenarında I. Mahmûd'la (salt. 1730-1754) ilgili şiirler (doğumu, derse başlaması, sakal bırakması, cülûsu); yk. $37^{\mathrm{b}}-68^{\mathrm{b}}$ de III. Ahmed'in (salt. 1703-1730) Patrona İsyanı (1730) ile tahtı bırakmadan önceki son beş günü ile I. Mahmûd'un tahta geçtiği 15 Rebiülevvel 1143’ten (28 Eylül 1730) 27 Safer 1144'e (31 Ağustos 1731) kadar İstanbul'da cereyan eden olaylar anlatılmaktadır. Mevcut rûznâme biçiminin ilk örneği kabul edilen ve R̂ैznâme ${ }^{7}$ adı verilen bu eser üzerine Hakan Yılmaz son zamanlarda ayrıntılı bir değerlendirme yapmış ve eserin ikinci bir nüshasını da ortaya çıkarmıştır. ${ }^{8}$

Sadece I. Mahmûd'la ilgili olan Mecmûa'nın sultana sunulmak üzere hazırlandığı aşikâr olmakla birlikte nüshanın üzerinde I. Mahmûd'un eseri gördügüne dair bir ipucu bulunmamaktadır. Kitap meraklısı olan sultanın kendisiyle ilgili bir kitabın koleksiyonuna katılmasıyla ona mührünü vuracağına şüphe yoktur. Öte yandan, yazmanın kenarlarına da şiirler yazdığına göre Hıfzî Ağa'nın bu nüshada bilgi toplaması yapıp notlar aldığını derle-

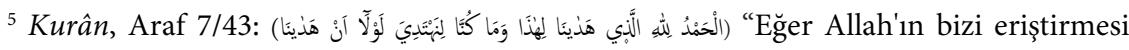
olmasaydı, biz hidayete ermiş olamazdık." http://kuran.diyanet.gov.tr/mushaf/kuranmeal-2/araf-suresi-7/ayet-43/diyanet-isleri-baskanligi-meali-1 [Erişim 18.11.2019]

${ }^{6}$ Sultan III. Mustafầnın bu vakıf mührü, kitabın sultanın Topkapı Sarayı'nda bulunun iki koleksiyonundan birisi olan Has Oda Kütüphanesi'ne (Revan Köşkü) dâhil edildiğini göstermektedir: Erünsal 2015: 180, 218.

${ }^{7}$ Eserin çeviriyazısı bitirme projesi olarak yapılmıştır: (Çınar 1974).

8 Yılmaz 2018: 189-191'de Belgrad Üniversitesi Svetozar Marković Library, T Pco, nr 327/7. 126 yapraktan oluşan Çelebizâde Âsım'ın Târîhçe'sinin de olduğu Mecmûa'nın son kısmında (yk. 87b-126a) R̂̀znâme'nin ikinci nüshasının yer aldığını belirtilmektedir. Yılmaz’ın yaptığı değerlendirmeye göre Belgrad nüshası ana müsveddeden istinsah edilmiştir ve Revân nüshası ise Hıfzî̀nin metni gözden geçirip tashih ederek güncel olayları da eklemeyi tasarladığı en son versiyonu temsil etmektedir. Yılmaz 2018, dpt 33'de her iki nüshanın edisyon kritiğini yaparak neşre hazırladı̆̆ını belirtmektedir. 
meyi tamamladıktan sonra tebyiz etmeyi/ettirmeyi planladığını düşünebiliriz..$^{9}$ Şimdilik I. Mahmûd'la ilgili şiirlerin toplandığı bu eserin temize çekilmiş hâli olabilecek bir nüshaya ulaşılamamıştır.

\section{Hıfzî Ağa/ Hıfzî Mehmed Efendi: Mürettip ve Yazar}

Hıfzî Ağa/Hıfzî Mehmed Efendi’nin hayatıyla ilgili bulabildiğimiz bilgileri değerlendirmeden önce birincil ve ikincil kaynaklarda geçen Hıfzî Ağa/Hıfzî Mehmed Efendi'nin aynı kişi olduğunu vurgulamak isteriz. Bu karışıklık, sır kâtibi olarak bilinen anlamda ilk rûznâmeyi kaleme alan Hıfzî Ağa'nın kendisinden ziyade Rûznâme'sinin ilgi çekmesi, bu görevden ayrıldıktan sonra ne yaptığının üzerinde durulmaması ve yeni göreviyle birlikte (gümrük başkâtipliği) ağa unvanından efendi unvanına geçmesinden kaynaklanmaktadır. Dolayısıyla Hıfzî Ağa ile Hıfzî Mehmed Efendi'nin aynı kişi olduklarının farkına varılmamıştır.

Hıfzî Ağa'nın hayatı hakkında en ayrıntılı ve güvenilir bilgi Müstakîmzâde Sadeddîn Efendi'nin Tuhfe-i Hattatîn adlı eserinde bulunmaktadır: (Müstakimzâde 2011: 375-76) Şehrî yani İstanbullu olan Mehmed Hıfzî̀ ${ }^{10}$ mukâtaât mültezimlerinden Süleymân'ın oğludur. Galata Sarayı'nda Kurân-1 Kerîm hıfzı tahsilini yaparken o sırada sarayda hoca olan Mehmed

${ }^{9}$ Öte yandan bir önceki dipnotta belirtildiği üzere Hakan Yılmaz bu nüshanın tashih edilmiş nüsha/nüshadan geldiğine işaret etmektedir. Revan 1977'nin versiyonlar arasında kaçıncı sırada olduğunun tespiti için araştırma ve incelemelerin devam etmesi gerektiğini belirtmek isteriz.

${ }^{10}$ Râmiz, Tezkire'sinde, "Ḥıfżī-i dīger” başlığı altında Hıfzî̀den kısaca söz etmekte ve isminin Mustafâ olduğunu belirtmektedir. Bu bilgi başka bir kaynaktan şu ana kadar teyit edilememiştir. Râmiz “İslâmbol şehrîlerinden” olarak tanıttığı Hıfzînin şairliğinden övgüyle söz edip gümrük kitabetinde çalıştı̆̆ını yazar fakat eğitimine ve sarayda görev almış olmasına temas etmez. Eyüp Sultan Türbesi’nde Hz. Muhammed’in Kadem-i Şerif inin bulunduğu yerin tamir edilmesine düşürdügü târîhin buraya yazıldığını ekler ve şiirlerinden örnek vermez. Bkz. Rāmiz ve Ādāb-ı Zurafā'sı 1994: 80. Hıfzî, Fatîn Tezkiresi'nde ise Mehmed Hıfzî Efendi olarak geçmekte, kısaca sarayda bir süre çalıştıktan sonra emtia gümrük başkitabeti hizmetiyle çerağ edildiği belirtilmekte ve eksik bir gazeli örnek verilmektedir. Fatîn Efendi 1271 [1870]: 102. 
Râsim Efendi'den ${ }^{11}$ (ö. 1169/1756) sülüs ve nesih meşk ederek icazet almıştır. İstinsah ettiği bir Enâm-1 Şerîf in besmelesini hocası Râsim Efendi'ye12 yazdırmıştır. Bu nüshanın III. Ahmed'e takdim edilmesi ve sultan tarafından beğenilmesi, Yenisaray’a (Topkapı) geçmesine vesile olmuştur. Yenisaray'a geçtikten sonra edebe uygun olarak İmâm-1 Câmi-i Mîrâhûr Emîr Efendi'den $^{13}$ (Yedikuleli Emîr Efendi/Hâş̧imîzâde Abdullâh Efendi ö. 1144/1731) de meşk etmiş, sultanın isteğiyle imtihan olup icazet almıştır. Mesleğinde ilerleme göstererek I. Mahmûd'un saltanatının ilk yıllarında sir katibi olan Hıfzî, bir süre sonra İstanbul gümrügü başkatipliğine atanır. Bu görevdeyken hacca gider ve dönüşte vefat eder (1173/1759-60), Eyüp Sultan'da annesinin mezarının yakınına defnedilir.14 Ayvansaray'da Dervişzade Sokağı'nda bulunan Emîr Buhârî Hankâhı/Tekkesi şeyhi Tatar Hâce Ahmed Efendi'ye (Kırîmî Şeyh Ahmed Efendi, ö. 1156/1743) intisap eden Hıfzî, bu tekke için Kurân cüzleri yazıp vakfetmiştir. Müstakîmzâde son olarak Eyüp Sultan Türbesi dışında Hz. Muhammed'in kadem-i şerîfi için yapılan inşa işleri için yazdığı manzumenin târîh mısraını kaydeder: Makâmın buldu resm-i pây-ı sultân-ı rusül hakkâ $1144 .{ }^{15}$

${ }^{11}$ Eğrikapılı Çelebi Efendi, Hoca Mehmed Râsim ve Çelebi Efendi olarak da tanınan Mehmed Râsim Efendi de Yedikuleli Seyyid Abdullâh Efendi'nin öğrencisi olup 11261150 (1714-1737) tarihleri arasında Galata Sarayı'nda meşk hocalığı görevinde bulunmuştur. 1150'de (1737) çok arzu ettiği Topkapı Sarayı'nda hat hocalığı ve saray kâtibi makamına geçmiştir. Hayatı hakkında bkz. Baysun 1954: 1-16; Şengün vd. 2011: 77 92.

${ }^{12}$ Râsim Efendi ile Hıfzînnin ilişkisinin sadece hat değil şiir üzerinden de devam ettiği anlaşılmaktadır. Şair olarak öğrencisi Hıfzîyyi başarılı bulan Râsim, onun bir şiirini tanzîr etmiştir. Râsim'in tanziri için bkz. Öksüz 2010: 193-94.

${ }^{13}$ Dönemin ünlü hattatı ve hat hocasıdır. Hayatı hakkında bkz. Müstakimzâde 2011: 249-50.

${ }^{14}$ Müstakîmzâde, "Şeyh Hamdullâh Efendi” ibaresinin vefatına târîh olduğunu belirtir ki ebcede göre toplam 1173 çıkmaktadır. Diğer birçok hattatın Şeyh Hamdullâh'la bir şekilde olan bağına işaret eden Müstakîmzâde, Hıfzî için herhangi bir bilgi vermemekle birlikte vefatıyla ilgili bu ibareyi belirtmesi onun Şeyh Hamdullâh'a hayranlığına ya da onun kadar başarılı yazdığına işaret edebilir. Mesela Müstakîmzâde, Eğrikapılı Râsim'i anlatırken Şeyh Hamdullâh kadar başarılı olduğunu vurgulamak için Şeyh'i takliden yazdığı bir yazının aslından ayırt edilemediğini ve maddi değerinin aynı olduğunu vurgular. Râsim'in öğrencisi olan Hifzînnin de Hamdullâh'a hayranlık duyup döneminde onu taklitte başarılı kabul edildiğini tahmin edebiliriz.

${ }^{15}$ Beş beyit olan manzumenin tamamı "Târîh-i Hıfzî Kâtib-i Gümrük Berây-1 Kadem-i Şerîf der Eyyûb” başlı̆̆ı ile Ayvansarâyînnin Mecmûa’sında yer almaktadır. Bkz. Hâfız 
Fikret Sarıcaoğlu, "Rûznâme," maddesinde (Sarıcaoğlu 2008: 278-81) Sir kâtibi Hıfzî Ağa’nın 23 Safer 1151'de (12 Haziran 1738) sır katipliği görevini Salâhî Efendi'ye devrettiğini yazar. Dolayısıyla 1151'den (1738) ölümüne kadar (1173/1759-60), Gümrük'te çalışan Hıfzî̀nin yaşamının böylece iki döneme ayrıldığı görülmektedir. Öte yandan, sarayda görevli olduğu sırada kaleme aldığı veya derlediği eserlerle ilgili olarak sonradan yaptığı herhangi çalışmanın izine şimdilik rastlanmaması dikkat çekicidir. Yapılacak çalışmalar hayatında ve çalışmalarında keskin bir yol ayırımının olup olmadığını ortaya koyabilir ve eğer böyle bu durum varsa sebepleri meydana çıkarılabilir.

Aynı şekilde Mecmûa'daki eserlere telif/tertip açısından bakıldığında ise Hıfzînnin iki farklı konumu olduğu ileri sürülebilir. I. Mahmûd’a yazılmış şiirlerin olduğu ilk eserde Hıfzî Ağa derleyici konumunda olup sultanın yaşamındaki önemli olaylar için farklı şairler tarafından yazılmış şiirleri toplamış ve kurguladığı tasnife göre sıralamıştır. İkinci eserin başlı̆̆ı nüsha üzerine kaydedilmemiş olmamakla birlikte "Rûznâme" adıyla tanınmakta ve bu türün ilk örneği olarak kabul edilmektedir. Hıfzî Ağa, mensur olarak kaleme aldığı bu bölümde ise derleyenden ziyade telif eden konumuna geçmektedir. Mürettip/derleyen ile müellif/musannif konumlarının Osmanlı bağlamında ve özellikle Hıfzî Ağa'nın yaşadığı dönemdeki algılanması üzerine ayrıntılı inceleme yapıldıktan sonra birşey söylemek mümkün olabileceği için şimdilik sadece bu duruma işaret etmekle yetiniyoruz.

Sonuç olarak Hıfzî Ağa'nın iki Rûznâme'si, bir şiir mecmûası ve muhtelif yerlerde tesadüf edilen şiirleri bulunmaktadır. R̂̂znâme'lerden ikincisinde adı Mehmed Salâhî̀yle birlikte geçmektedir. ${ }^{16}$ Zabt-ı Vekâyi-i Yevmiyye-i Cenâb-ı Hazret-i Şehriyârî/Zabt-ı Vekâyi-i Șehriyârrî adlarıyla tanınan eserin nüshası İUK-TY 2518, yk. 2b-198b'dedir. İncelediğimiz Mecmûa'da Hıfzî̀nin adına kayıtlı şiir sayısı ise $7^{\prime}$ dir. ${ }^{17}$

Hüseyin Ayvansarâyî 1985: 112. Bu beş beyitlik manzume kitabe hâline getirilmiştir ve hâlen Eyüp Sultan Türbesi'nde kıbleye bakan duvarın içine yerleştirilmiş olan "Kadem-i Saadet"in üzerinde bulunmaktadır.

16 Sarıcaoğlu 2008: 278-81'de Hıfẑ̀ye ait iki Rûznâme'den söz edilir, ikincisini Salâhî Efendi tamamladığ 1 için kaynaklarda iki müellifin eseri olarak geçtiği belirtilir.

${ }^{17}$ Dipnot 12'de işaret edildiği üzere hocası Hattat Râsim Efendi, Hıfzî̀nin şiirini beğenip tanzir etmiştir. En azından kendi çevresinde şair olarak beğenildiğini öne sürebileceğimiz Hıfzînnin şiirlerinin Dîvân olarak tertip edilip edilmediğini bilmemekle birlikte 


\section{Mecmûa'nın Manzum Kısmı ve Yapısı}

II. Mustafầnın (salt. 1695-1703) büyük oğlu olan I. Mahmûd, amcası III. Ahmed'in Patrona Halîl İsyanı'yla tahtan indirilmesi üzerine 19 Rebiülevvel 1143 (2 Ekim 1730) tarihinde tahta geçmiştir. I. Mahmûd'un tahta çımasına vesile olan olaylar ve sıkıntılar, sultan değişikliğine rağmen bir süre daha devam etmiş ve ancak 29 Safer 1144'den (2 Eylül 1731) sonra yeni sultan yönetime tam anlamıyla hakim olabilmiştir. Gerek I. Mahmûd'un tahta geçmesine vesile olan isyanı, gerekse tahta geçtikten sonraki olayları yazılı olarak ifade eden çeşitli metinler kaleme alınmıştır. ${ }^{18}$ Bunlar arasında başta târîh manzumeleri olmak üzere çok sayıda şiir bulunmaktadır. Hıfzînnin yazılan bu şiirlerden bir seçme yaptığı anlaşılmaktadır. Zira, Hıfzînnin derlemesine almadığı, özellikle I. Mahmûd'un cülûsu üzerine yazılan, şairlerin

şimdilik elde ona ait Dîvân nüshasının bulunmadığına işaret etmek gerekir. Saray’a olan yakınlığından dolayı onun kaleme aldığını ileri sürebileceğimiz târîh manzumeleri arasında 1147 (1734-35) tarihli Topkapı Sarayı 3. Avludaki Kuşhane Kapısı'nın; 1171 (1757-58) tarihli Hekimoğlu Alî Paşa'nın Türbesi'nin; 1151 (1738-39) tarihli Hacı Beşîr Ağa'nın Eyüp'teki çeşmesinin târîhinin bulunduğunu belirtebiliriz. Hacı Beşîr Ağa'nın Sirkeci'deki camiine 1158'de (1745-46) târîh manzumesi yazdığı bilgisi tamir kitabesinde yer almaktadır. Bu manzumeler, http://www.ottomaninscriptions.com adlı veritabanından tespit edilmiş olup yeni künyeler eklendikçe Hıfzînnin daha fazla şiiri gün ışı̆̆ına çıkabilir. Öte yandan bu şiirlerin bu dönemde yaşamış Rāmiz ve Ādāb1 Zurafā'sı (1994): 80'de geçen Mehmed isimli 1166'da (1752-53) vefat ettiği belirtilen Hıfzî̀ye aitliği az bir ihtimalle söz konusudur. Müminzâde Hasîb’in Hekîmoğlu Alî Paşa'nın ikinci kez sadrazamlığa (15 Safer 1155/21 Nisan 1742) atanmasına yazılan şiirleri topladığı Mecmûa'sında Hıfzî adına dört şiir bulunmaktadır. Bunların burada sözü edilen Hıfzîlerden hangisine ait olduğunu tespit için ayrıca araştırma yapmak gerekir. Ayrıca, Hasîb'in Mecmûa'sına aldığ Hıfzî mahlaslı şiirlerden birinin başlığında şöyle yazılıdır: Târîh-i Hıfzî Efendi Kitâbc1-1 Sadr-1 'Âlî (161-62/32). Bu durumda bilinen iki Hıfzînnin dışında üçüncü bir Hıfzî mahlaslı şairin olabileceği ihtimali ortaya çıkmaktadır. Eğer böyle bir durum varsa Hekîmoğlu'nun türbesindeki târîh manzumesinin de bu şair tarafından yazılmış olma ihtimali daha yüksektir. Bkz. İnan 2013: 146-47; 161-62; 246-49.

${ }^{18} \mathrm{Bu}$ konuyla ilgili başta Münir Aktepe'nin olmak üzere çok sayıda çalışma bulunmaktadır. Bunları burada tek tek zikretmek yerine toplu hâlde görülmesi için Hakan Yılmaz'ın yukarıda belirtilen makalesi ile Erhan Afyoncu'nun çalışmalarına bakılabilir. Afyoncu 2003: 101-72; Afyoncu 2006. 
dîvânlarında, ${ }^{19}$ başka mecmûalarda ${ }^{20}$ tarih kitaplarında ${ }^{21}$, tezkirelerde ${ }^{22}$ ve özellikle TSMA'de bulunan ve saraya takdim edildiği anlaşılan çok sayıda şiirin bulunduğu dikkat çeker.

Hıfzî, seçtiği şiirleri Mecmûa'nın 2b varağından itibaren altı bölüme yerleştirmiştir. Bu altı bölümün beşi I. Mahmûd'un yaşamının dönüm noktalarıdır. Doğum, derse başlama, sakal bırakma, cülûs ve tahta çıtıktan sonra medhiye amacıyla ve yeni yıl nedeniyle kendisine sunulan şiirler şeklinde yaptığı tasnif Hıfzînin bu Mecmûa'yı derlemeyi tasarladığı diğer ifadeyle gün gün karşısına çıkanları eklediği bir mecmûadan ziyade sır katibi olarak sultana takdim edilen şiirlere kolay ulaşabilme imkânından yararlanarak bugün TSMA'de bulunan farklı şairlerin sunduğu şiirlerin yazılı olduğu yaprakları görüp bunlardan seçme yaptığını tahmin edebiliriz. Arşivde bulunan şiirler ile bu Mecmûa'daki şiirlerin karşılaştırılması bu konuda nihai karar verme imkanı sunabilecektir. ${ }^{23}$ Hıfzî zihnindeki tasnifi şu başlıklar hâlinde sıralamıştır:

1) Tevârîh-i vilâdet bâ-saâdet-i hazret-i pâdişâh-1 İslâm hullidetü'lhilâfe ilâ yevmi's-sâ'ati ve's-sâ'ati'l-kıyâm: 4

2) Târîh berây ibtidâ-kerden-i ders be-hâce-dâden-i Hazret-i Şehriyâr-1 cihândâr halledallahu mülkehu ilâ yevmi'l-karâr: 1

3) Tevârîh-i lihye-nihâden-i Hazret-i Pâdişâh-1 âlem-penâh dâme lehu'l-izzü'l-câh ${ }^{24}: 3$

19 Mesela Arpaemînîzâde Sâlim'in Dîvân'ındaki iki cülûsiyesi. Bkz. Arpaemîni-zâde Mustafa Sâmî 2004: 350-55; Nebzînin (ö. 1175/1762'den sonra) cülûsla ilgili ikisi kaside, biri kıt'a nazım biçiminde üç târîh manzumesi bulunmaktadır. Bkz. Okumuş 2007: 195-97.

${ }^{20}$ Mesela Ayvansarâyî 1985: 11'de Reşîd'in, 167-68'de Seyyid Feyzî ve Fennî̀nin târîhleri.

${ }^{21}$ Mesela Abdî̀nin bir târîh manzumesi için bkz. 1730 Patrona İhtilâli Hakkında Bir Eser Abdi Tarihi 1943: 65.

${ }^{22}$ Mesela şimdilik Dîvân'ına ulaşılamayan Buharalı Agâh'ın cülûs için târîh manzumesi yazdı̆̆ı bilgisi Râmiz ve Âdâb-ı Zurafâ'sı 1994: 14'de kayıtlıdır.

${ }^{23}$ Mesela TSMA'da bulunan dolayısıyla saraya sunulan Müftîzâde Mehmed Muhibbî’nin, on sekizinci yüzyıl kaynaklarında adı geçen hiçbir Fâiz'le örtüşmeyen Fâiz’ in şiirleri Hıfzî’nin Mecmûa'sında bulunmamaktadır. Mahmûd'un cülûsu için yazılan şiirler üzerine bir yazıyı yayına hazırlamaktayız.

${ }^{24}$ Pakalın 1993, III: 476-77’de tahta geçen sultanın sakal bırakmasıyla ilgili şunlar yazılmaktadır: "Hükümdarlığa geçen şehzade cülusunu müteakip tıraş olur ve ondan sonra 
4) Tevârîh-i ma'rûza berây-1 cülûs-1 hümâyûn-1 şevket-makrûn ve teşrîf-kerden-i hazret-i pâdişâh-1 rub'-1 meskûn be-serîr-i saltanat-1 gerdûnnümün ebedallâhu devletuhu'l-emîn: 51

5) Tevârîh-i ma'rûza berây-1 sene-i cedîde (1144 senesi): 5

6) I. Mahmûd'ın cülûsu ve medhi amacıyla yazılan çeşitli şiirler (bu kısmın başlı̆̆1 yoktur): 16

Altı bölümde yer alan toplam şiir sayısı 80’dir.

Mecmûa'nın "Rûznâme” bölümünde derkenarda ise toplam 20 manzume bulunmaktadır. Bunların 9 tanesi manzum kısımda yer alan târîh beyitlerinin aynısıdır. ${ }^{25}$ Kalanın biri, Şâkir'in cülûs için yazdığ 1 müfreddir. Diğer 9 tanesi ise gündemin diğer önemli konusu olan atamalarla ilgili olup Patrona Halil İsyanı'nı sırasında ve sonrasında çeşitli vazifelere yapılan atamalar için yazılan târîhlerdir. Bunlar Rûhî̀nin Mîrzâzâde (Şeyh Mehmed) Efendi'nin (ö. 1147/1735) 17 Rebîülevvel 1143'de (30 Eylül 1730) Şeyhülislâm atanması (38 ) (İpşirli 2005: 170), İmâmzâde Efendi'nin (ö. 1145/1732-33) Nakîbüleşrâf olması (38 ${ }^{\mathrm{a}}$ ) Işık (2014: 222), Kaplan Geray'ın Kırım Hanı (42a ${ }^{26}$ olması, Mîrzâzâde Sâlim’in (ö. 1156/1743) Cemâziyelevvel 1143'de (Kasım 1730) Anadolu Kazaskeri olması (48ª) (Güfta 2009: 46), Hekîmzâde Ebûbekir Efendi'nin (ö. 1167/1754) Cemâziyelevvel 1143'de (Kasım 1730) İstanbul kadısı olması (48b) (Mehmed Süreyyâ, 1308[1891]):177), Kabakulak İbrâhîm Paşa'nın (ö. 1155/1743) 13 Receb 1143'de (22 Ocak 1731) vezir-i azam olması (53ª) (Uzunçarşılı 1995: 318); Hifzî̀nin Silâhdar Mehmed Paşa'nın $\left(38^{\mathrm{b}}\right)^{27}$ vezir olması, Saray Sofası'na bir havuz yapılması $\left(64^{\mathrm{b}}\right)$ ve Esad'ın padişahın "savaş kazanması" (62 $\left.{ }^{\text {b }}\right)$ ile ilgili yazdığı manzumelerdir. Şairi kaydedilmemiş olan bir beytin ise isyan zamanında söylendiği, ayaklanmanın elebaşlarının yakalanması için edilen dua mahiyetinde olmasından anlaşılmaktadır $\left(48^{\mathrm{a}}\right)$.

sakal bırakırdı. İşte buna "tesrih-i lihye” denilirdi. Küçük yaşta hükümdar olanlar yaşları yirmiyi geçince sakal koyverirlerdi.” Ayrıca bkz. Uzunçarşılı 1988: 188.

${ }^{25}$ Bunlar listede gösterilmiştir.

${ }^{26}$ I. Kaplan Geray üç defa Kırım Hanı olmuştur (1707-1708, 1713-1716, 1730-1736). Kançal-Ferrari 2005: 314.

${ }^{27}$ Uzunçarşılı 1995: 316'da Patrona Halil İsyanı'na katılanlar ile mücadelesi karşıllı̆ında Mehmed Paşa'ya vezirlik payesi ile birlikte Halep valiliği verildiği yazılıdır. 
Yukarıda görüleceği üzere $M e c m \hat{u} a$ 'daki şiirlerin çoğunluğu (51 adet) I. Mahmûd'un tahta cülûsu üzerine yazılmıştır. ${ }^{28}$ Tebrik amacıyla yazılan cülûsiye şiirleri aynı zamanda dönemin yönetici sınıfına mensup olan şairlerin kendilerini yeni sultana tanıtması/takdim etmesinde önemli bir aracı konumundadır. Yazılan şiirlerin takdim edilip edilmemesinde şairin sarayla olan ilişkilerinin etkin rol oynadığı görülmektedir. Sunulma fırsatı bulunmamış şiirlere şairin dîvânında ve çeşitli maksatlarla derlenmiş mecmûalarda rastlamak mümkün olabilmektedir.

Mecmûa'nın manzum kısmının başında eserin "Mukaddime"si mahiyetinde iki sayfada ( $1^{\mathrm{b}}$ ve $\left.2^{\mathrm{a}}\right)$ I. Mahmûd'un tahta çıkış yılı olan hicri 1143 (1730) tarihi ile ilgili bazı mensur açıklamalar vardır. Ayrıca şairi kayd edilmemiş/belli olamayan şiirler bulunmaktadır. Bunlar manzum kısımda 10, Rûznâme'nin derkenarında 1 olmak üzere toplam 11 tanedir.

\section{Mecmûada Şiirleri Bulunan Şairler}

Mecmûada şiiri bulunan şair sayısı 53'tür. Aşağıda bu şairler mahlaslarına göre alfabetik sıralanarak mümkünse kesinleşmiş ölüm tarihleri, bulunabildiği ölçüde haklarında dipnotta kısaca bilgi ve ilgili kaynağa gönderme yapılıp şiirlerinin sayıları ve bulundukları varakların numaraları yazılmıştır.

Tablo: Mecmûa'da şiirleri bulunan şairler ve şiir sayıları

\begin{tabular}{|l|l|}
\hline Şair & Şiir sayısı ve bulunduğu yaprak \\
\hline $\operatorname{Abdî̀}^{29}$ (ö. 1150/1737-38) & 1 manzume, yk. 22a \\
\hline
\end{tabular}

${ }^{28}$ Tahta yeni bir sultanın çıkması vesilesiyle kasîde, târîh manzumesi ya da kasîde-târîh manzumesi başta olmak üzere yazılan şiirlerin Osmanlı bağlamındaki tarihî seyri üzerine şimdilik müstakil bir çalışma yapılmamıştır. Belirli bir yüzyıla yönelik bir çalışma için bkz. Özer 2017: 1-14.

${ }^{29} \mathrm{Bu}$ yüzyılda yaşamış birden çok Abdî mahlaslı şair bulunmakla birlikte bu cülûsiyenin Patrona ayaklanmasını, başlangıcından bastırılmasına kadar ayrıntılı olarak anlatan Târîh-i Sultân Mahmûd Han İbni Sultân Mustafâ Hân adını taşıyan fakat daha çok Abdî Tarihi adıyla bilinen kitabın yazarı olan Abdülbâkî Abdî Efendi’ye ait olma ihtimali fazladır. Abdî Efendi’nin kimliği üzerinde sınırlı olan bilgiler Hakan Yılmaz’ın yayımlanan makalesiyle birlikte gün ışı̆̆ına çıkmıştır. Buna göre Kevâkibîzâde Veliyyüddîn Efendi'nin oğlu olan Abdülbâkî Efendi'nin kadılık görevlerinde de bulunmuş saraya davet edilecek kadar itibarlı bir müderris olduğu anlaşılmaktadır. Bkz. Yılmaz 2019: 245-51. 


\begin{tabular}{|c|c|}
\hline Ahmedîn $^{30}$ & 1 manzume, yk. $15^{\mathrm{b}}$ \\
\hline Âzim ${ }^{31}$ & 1 manzume, yk. $20^{\mathrm{a}}$ \\
\hline Bağdâdî $^{32}$ (ö. 1153/1740-41) & 1 manzume, yk. $3^{\mathrm{a}}$ \\
\hline Emrîi $\hat{i}^{33}$ & 1 manzume, yk. $11^{\mathrm{b}}$ \\
\hline $\operatorname{Esad}^{34}$ (ö. 1166/1753) & 1 manzume, yk. $62^{\mathrm{b}}$ \\
\hline Fasîhî̀ ${ }^{35}$ (ö. 1156/1740) & 1 manzume, yk. $16^{\mathrm{a}}$ \\
\hline Feyzîn & 1 manzume, yk. $8^{\mathrm{b}}$ \\
\hline Hâfız-1 Şîrâzîin (ö. 792/1390 [?]) & 1 manzume, yk. $2^{\mathrm{a}}$ \\
\hline Hâfiz ${ }^{38}$ (ö. 1157/1744-45) & 1 manzume, yk. $10^{\mathrm{a}}$ \\
\hline Hâkî39 (ö. 1173/1759-60) & 1 manzume, yk. $31^{\mathrm{a}}$ \\
\hline
\end{tabular}

${ }^{30}$ TDEA 1977, I: 80'de geçen İşkodra'da doğmuş, müderrislik yapmış, 1737'de vefat etmiş mutasavvıf şair Ahmedî olabilir.

${ }^{31}$ Müstakimzâde 2011: 685’te Seyyid Mustafâ (Âzim) olarak geçen Bursa'nın ileri gelenlerinden, hatt meşk etmiş ve şairliğe meraklı Âzim olabilir.

${ }^{32} \mathrm{Bu}$ asırda yaşayan ve Bağdâdî mahlasını kullanan birkaç şair olmakla birlikte Müstakimzâde 2011: 532'de Yûsuf (Bağdâd) olarak geçen Mehmed Ârif-i Mevlevî'den hat meşk edip 1153'de (1740-41) vefat etmiş olan Bağdatlı Yûsuf olma ihtimali bulunmaktadir.

${ }^{33}$ Şair olarak hiçbir kaynakta yer almamaktadır ve TSMA'da da manzumesi vardır.

${ }^{34}$ Şeyhülislâm Esad Efendi olup bu cülûsiyesi yayımlanmış Dîvân'ında bulunmamaktadir. Bkz. Doğan 1997a.

${ }^{35}$ Hasan Fâsihî Efendi (ö. 1156/1743) olabilir, fakat Dîvân'ında cülûsiye yer almamaktadir. Bkz. Gökalp 2001.

${ }^{36} \mathrm{Bu}$ yüzyılda yaşamış birden çok Feyzî mahlaslı şair bulunmaktadır, şimdilik hangisi olduğu tespit edilemedi. Ancak sırasıyla Müstakimzâde 2011: 206-07 ve 590'da adları geçen Seyfullah-1 Feyzî (Feyzî) (ö. 1148/1735-36) ve Hüseyn-i Feyzîden (Feyzî, ö. 1142 'den sonra/1730) biri olabilir.

${ }^{37}$ Hâfız-1 Şirâzî Fars edebiyatının tanınmış şairlerindendir. Mecmûa'da 3 beyti yazılmış gazelin tamamı için bkz. Hâfız-1 Şîrâzî 1992: 483.

${ }^{38}$ Râmiz ve Âdâb-ı Zurafâ'sı 1994: 67'de geçen fenn-i târîh'de mahir olan Galatalı Hâfız'dır. Râmiz hem Sultan III. Ahmed'in ölümüne hem de I. Mahmûd'un cülûsuna yazdığı târîh manzumelerinin târîh mısraını/beytini kaydetmiştir.

39 Müstakimzâde 2011: 444'de Kilisli Mehmed Hâkî̀nin Alaca Mescidi İmamı Alî-i Sânî'den hat meşk ettiği ve kâtip olduğu yazılıdır. 


\begin{tabular}{|c|c|}
\hline $\operatorname{Hamdîn}^{40}$ (ö. 1164/1750-51) & 1 manzume, yk. $11^{\mathrm{b}}$ \\
\hline Hâsım/Hâsim ${ }^{41}$ & 2 manzume, yk. $7^{b} / 39^{a}-8^{a}$ \\
\hline Hifzîi $^{42}$ (ö. 1173/1759-60) & $\begin{array}{l}7 \text { manzume, yk. } 4^{\mathrm{a}}(2 \text { adet/1'i derkenarda }) \\
10^{\mathrm{a}}-24^{\mathrm{a}}-34^{\mathrm{b}}-38^{\mathrm{b}}-64^{\mathrm{b}}\end{array}$ \\
\hline Hikmet & 1 manzume, yk. $19^{a}$ \\
\hline Hilmî $^{43}$ & 2 manzume, yk. $10^{\mathrm{b} /} / 39^{\mathrm{a}}-33^{\mathrm{b}}$ \\
\hline 'İlmî̀ (ö. 1151/1738-39) & 3 manzume, yk. $14^{\mathrm{a}}-14^{\mathrm{b}}-24^{\mathrm{b}}$ \\
\hline İshak Efendi $^{45}$ (ö. 1447/1734) & 1 manzume, yk. $4^{\mathrm{b}}$ \\
\hline Kadrî & 1 manzume, yk. $18^{\mathrm{b}}$ \\
\hline Kâmî̀ (ö. 1136/1724) & 1 manzume, yk. $3^{\mathrm{a}}$ \\
\hline Kâmil & 1 manzume, yk. $16^{\mathrm{b}}$ \\
\hline Kâşifî́ ${ }^{47}$ & 1 manzume, yk. $17^{\mathrm{a}}$ \\
\hline Kutûbî & 1 manzume, k. $31^{\mathrm{b}}$ \\
\hline
\end{tabular}

${ }^{40}$ Râmiz ve Âdâb-ı Zurafâ'sı 1994: 83'de geçen Câbî Remzîzâde Ahmed Hamdî Efendi (ö. 1164/1750-51) olabilir.

${ }^{41}$ Diyarbakırlı İbrâhîm Hâsım Efendi'dir. Mirzazâde Mehmed Sâlim Efendi 2018: 165. TDEA 1981, IV: 137'de Mecmûa'da bulunan manzumenin târîh beyti vardır.

${ }^{42}$ Mecmûa'yı derleyen Hifzî̀ dir.

${ }^{43}$ Râmiz ve Âdâb-ı Zurafầ'sı 1994: 82'de Enderûn ricalinden olup bu devirde vefat ettiği belirtilen cülûsiyesinin tarih beyti övgüyle alıntılanan Enderunlu Abdülhalîm Efendi'dir.

${ }^{44}$ Râmiz ve Âdâb-ı Zurafâ'sı 1994: 231'de geçen ve övgüyle söz edilen âlim ve şair Trabzonî İlmî Efendi'dir.

45 Şeyhülislâm İshak Efendi'nin Dîvân'ında Sultan I. Mahmûd için yazılmış 4 adet kasîdesi vardır. Bkz. Doğan 1997b: k26: 216-219, k29: 226-230, k30: 230-234 ve k31: 234-238. Fakat Mecmûa'daki târîh manzumesi matbu Dîvân'da yer almamaktadır.

46 Ünlü şair Edirneli Kâmî olup, tarih manzumesi "Târîh-i berây-1 vilâdet-i Sultân Mahmûd" başlı̆̆ı altında Dîvân'ında yer almaktadır. Yazıcı 1998: 129.

${ }^{47}$ Râmiz ve Âdâb-ı Zurafâ'sı 1994: 250-51'de eğitimi ve mesleğine dair hiçbir bilgi verilmeden I. Mahmûd döneminde şiire başlayıp şâir-i mâhir olarak nitelenen ve cülûs için yazdığı manzumeden şiirine örnek olarak verilmesi planlanan Kâşifî̀dir. 


\begin{tabular}{|c|c|}
\hline Mâhirî̀ $^{48}$ & 1 manzume, yk. $16^{\mathrm{a}}$ \\
\hline Mehmed & 2 manzume, yk. $20^{\mathrm{b}}-34^{\mathrm{a}}$ \\
\hline Mucîbî̀ $^{49}$ & 1 manzume, yk. $12^{\mathrm{a}}$ \\
\hline Muhlis $^{50}$ & 2 manzume, yk. $22^{\mathrm{a}}-32^{\mathrm{b}}$ \\
\hline Muhyîn & 1 manzume, yk. $17^{\mathrm{a}}$ \\
\hline Muslih $^{52}$ & 1 manzume, yk. $19^{\mathrm{b}}$ \\
\hline Münîf $f^{53}$ & 1 manzume, yk. $5^{a} / 39^{a}$ \\
\hline Nahîfî Efendi ${ }^{54}$ (ö. 1151/1738) & 1 manzume, yk. $5^{\mathrm{b}} / 39^{\mathrm{a}}$ \\
\hline $\mathrm{Na}$ îm $^{55}$ & 1 manzume, yk. $15^{\mathrm{a}}$ \\
\hline Nazîf $^{56}$ & 2 manzume, yk. $11^{\mathrm{a}}-24^{\mathrm{b}}$ \\
\hline
\end{tabular}

${ }^{48}$ Râmiz ve Âdâb-ı Zurafâ'sı 1994: 264'de I. Mahmûd dönemi şairi olarak geçmektedir. Başarılı bulunan şiirlerine örnek olarak cülûs tarihinin verileceği belirtilmekle birlikte yazılmamıştır.

${ }^{49}$ Râmiz ve Âdâb-ı Zurafâ'sı 1994: 264'de I. Mahmûd dönemi şairi olarak geçmektedir. Şiirlerine örnek olarak cülûs tarihinin verileceği belirtmekle birlikte yeri boş kalmıştır. ${ }^{50}$ TDEA 1986, VI: 431'de Muhlis mahlaslı iki şair vardır. Birincisi 1757'de vefat eden Mora hanedanından Koca Halîl Beyzâde Abdî Bey’in oğlu, Dergâh-1 Âlî Kapıcıbaşılarından olan Muhlis'tir. Diğeri ise 1772'de vefat eden Nevşehirli Muhlis'tir.

${ }^{51}$ Râmiz ve Âdâb-ı Zurafầ'sı 1994: 267-68'de isminin Muhyiddîn olması hasebiyle Muhyî mahlasını seçtiği belirtilmektedir. Bolu Sancağına bağlı Taraklıborlulu olan Muhyî fikıh âlimi, müderris ve fetva emini olarak tanınmaktadır.

${ }^{52}$ Râmiz ve Âdâb-ı Zurafâ'sı 1994: 264'de I. Mahmûd dönemi şairi olarak geçmekte ve adı Muslihiddîn olduğu için Muslih mahlasını seçtiği belirtilmektedir. Şiirlerine örnek olarak cülûs tarihinin verileceği belirtmekle birlikte yeri boş kalmıştır.

${ }^{53}$ Antakyalı Münîfe ait olabilir fakat Dîvân'ı üzerine yapılan çalışmalarda yer almamaktadır. Sarayla ilişkisi göz önüne alındığında az bir ihtimal olsa da Müstakimzâde 2011: 393'de geçen Mehmed-i Münîf bin Alî-i Âlî (Münîf) olabileceğini de işaret etmek gerekir.

${ }^{54}$ Süleymân Nahîfî, Dîvân'inda yer almaktadır. Bkz. Aypay 1992: 261-62.

55 TDEA 1986, VI: 502'de adı verilen Naîm Efendi (Moralı, ö. 1756'dan sonra) olabileceği gibi sayfa 503'teki Naîm Mehmed Efendi (Yazmacızâde, ö. 1752) de olabilir.

${ }^{56}$ TDEA 1986, C. 6: 542'da verilen Enderun'da yetişip kahvecibaşılık yapan ve daha sonra Hâne-i Hassa-i Hümâyûn Ağaları zümresine katılan Nazîf Mustafâ Efendi (Kahvecibaşı) olabileceği gibi Müstakimzâde 2011: 479'da geçen Münîf Efendi'den sonra İran

\section{Akademik Dil ve Edebiyat Dergisi}

Cilt/Volume: 3, Sayı/Issue: 4, Aralık/December 2019 


\begin{tabular}{|c|c|}
\hline Rahmîn $^{57}$ & 2 manzume, yk. $7^{a} / 39^{a}-32^{a}$ \\
\hline $\operatorname{Reşîd~}^{58}$ & 1 manzume, yk. $10^{\mathrm{b}}$ \\
\hline Riyâzî̀ ${ }^{59}$ & 2 adet, yk. $9^{\mathrm{b}}$ ( 2 adet $)$ \\
\hline Rûhî́ $\hat{1}^{60}$ & $\begin{array}{l}9 \text { manzume, yk. } 4^{\mathrm{a}}-6^{\mathrm{b}}-23^{\mathrm{b}}-38^{\mathrm{a}}(2 \text { adet })- \\
42^{\mathrm{a}}-48^{\mathrm{b}}(2 \text { adet })-53^{\mathrm{a}}\end{array}$ \\
\hline Sâbit $^{61}$ (ö. 1124/1712) & 1 adet, yk. $2^{\text {b }}$ \\
\hline $\mathrm{Sa}^{\prime} \mathrm{dì}^{62}$ (ö. 1161/1748-49) & 2 adet, yk. $3^{b}-9^{a}$ \\
\hline Sadîk & 3 manzume, yk. $14^{\mathrm{b}}-15^{\mathrm{a}}$ (2 adet) \\
\hline Sâhib Efendi & 2 adet, yk. $5^{a} / 39^{a}-13^{a}$ \\
\hline Sa'îd & 2 manzume, $14^{\mathrm{a}}-29^{\mathrm{b}}$ \\
\hline Salâhî́63 (ö. 1201/1787) & 1 manzume, yk. $9^{\mathrm{b}}$ \\
\hline Sâlim ${ }^{64}$ (ö. 1156/1743) & 1 manzume, yk. $26^{\mathrm{b}}$ \\
\hline
\end{tabular}

sefiri olan Anadolu Muhasebeciliği, Şehreminliği ve Sadaret Kethüdalığı görevlerinde bulunan Mustafâ Nazîf bin Ömer [Nazîf Kethudâ] (ö. 1168/ 1754) da olabilir.

${ }^{57}$ Bu cülûsiye Kırımlı Mustafâ Rahmî̀nin (ö. 1165/ 1752) Dîvânı’nda yer almamaktadır. Sarayla yakın ilişkisi düşünüldügünde ona ait olma ihtimali fazladır: Sevgi 1997.

${ }^{58}$ Râmiz ve Âdâb-ı Zurafầ'sı 1994: 128'de geçen Reşîd Rüşdî-zâde’ye (ö. 1152/1739-40) ait olabilir.

${ }^{59}$ Mehmed Süreyyâ 1311 [1893], II, 425’te I. Mahmûd devrinde vefat eden Riyâzînnin şair olduğunu kaydetmektedir.

${ }^{60}$ Râmiz ve Âdâb-ı Zurafầ'sı 1994: 1141'de geçen Üsküdarlı Rûhî'dir. Râmiz, I. Mahmûd döneminde vefat ettiğini belirtir ve $M e c m \hat{u} a$ 'da yer alan cülûsiyesinin târîh beytinin yanı sıra yazdığı diğer bir târîhin de mısraını alıntılar.

${ }^{61}$ Ünlü şair Bosnalı Sâbit olup, tarih manzumesi "Târîh-i vilâdet-i Şehzâde Sultân Mahmûd bin Sultân Mustafâ” başlı̆̆ı altında Dîvân'ında yer almaktadır. Bosnalı Alaeddin Sabit 1991: 326.

${ }^{62}$ Dürrî Ahmed Efendi'nin kardeşi olup Acem Sadî olarak tanınan Abdülbâkî Sadî Efendi'dir. Bkz. Râmiz ve Âdâb-ı Zurafâ'sı 1994: 161-62.

${ }^{63}$ Müstakimzâde 2011: 216'daki Sâlih-i Salâhî (Salâhî)'dir. Hifzî'den sonra sır kâtipliği görevinde bulunmuştur.

${ }^{64}$ Mîrzâ-zâde Mehmed Sâlim Efendi'dir. Mecmûa'daki kasîde ile Divân'ındaki arasında bazı farklılıklar mevcuttur. Mîrzâa-zâde Mehmed Sâlim Dîvânı: Tenkitli Basım 1994: 7682. 


\begin{tabular}{|c|c|}
\hline Şâkir65 (ö. 1157/1744-45) & 3 manzume, yk. $2^{a}-28^{a}-39^{a}$ \\
\hline $\operatorname{Şem}^{\prime} \hat{1}^{66}$ & 1 manzume, yk. $36^{\mathrm{a}}$ \\
\hline Şencer & 1 manzume, yk. $15^{\mathrm{b}}$ \\
\hline $\operatorname{Tab}^{\prime} \hat{1}^{67}$ & 1 manzume, yk. $18^{\mathrm{b}}$ \\
\hline Ulvì $^{68}$ & 1 manzume, yk. $22^{\mathrm{b}}$ \\
\hline Vâcid ${ }^{69}$ & 1 manzume, yk. $8^{\mathrm{b}} / 39^{\mathrm{a}}$ \\
\hline Vâhid $^{70}$ (ö. 1145/1732) & 3 manzume, yk. $19^{\mathrm{b}} / 39^{\mathrm{a}}-25^{\mathrm{a}}-35^{\mathrm{b}}$ \\
\hline Zâhirîîl & 1 manzume, yk. $12^{\mathrm{a}}$ \\
\hline Zülfî̀ & 1 manzume, yk. $3^{a}$ \\
\hline
\end{tabular}

${ }^{65}$ Gümrükçü Hüseyin Paşazâde Hüseyin Şâkir Efendi'dir. Bkz. Râmiz ve Âdâb-ı Zurafâ'sı 1994: 169-70. Şâkir'in Mecmûa'daki üç manzumesi de Dîvân'inda mevcuttur: Seyhan Yıldız 2002: 198'de 2 2'daki târîh kıt'asının tamamı, 17'de 28 ${ }^{\text {a' }}$ daki kasîdesi bazı farklarla

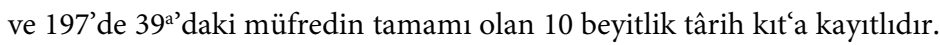

${ }^{66}$ Müstakimzâde 2011: 32'deki İbrâhîm Şemî̀ bin Ahmed [Şem‘î] (ö. 1176/1763) olma ihtimali fazladır. Hıfzî gibi Râsim Efendi’nin öğrencisi olmuştur.

${ }^{67}$ Müstakimzâde 2011: 485'te Mustafâ Tab'î bin Mustafâ (Tab'î) olarak geçmektedir. Hıfzî gibi Râsim Efendi’nin öğrencisi olmuştur.

${ }^{68}$ Fazile Eren Kaya, "Ulvî, Hüseyin Ulvî Efendi," http://www.turkedebiyatiisimlersozlugu.com/index.php?sayfa=detay\&detay=6602'de [Erișim Tarihi: 25.11 .2019$]$ 'da bir kasîdesinin saedce iki beytinin mevcut olduğu belirtilen Ulvî Efendi olabilir.

${ }^{69}$ Emine Sıdıka Toptaş, "Vâcid," http://www.turkedebiyatiisimlersozlugu.com/index.php? sayfa=detay\&detay=6200'da [Erișim Tarihi: 25.11.2019]'da bulunan Vâcid adındaki şairlerden hakkında çok kısa bilgi bulunan 1738-39'da Hanya'ya gittiği belirtilen olabilir.

${ }^{70}$ Vâhid Mahtûmî (ö. 1145/1732) tarafından yazılabileceği gibi Müstakimzâde 2011: 123'de geçen Ebû Bekr-i Vahîd bin Ebî Bekr [Vahîd, İstanbul Ağası-zâde]'ye de ait olabilir.

${ }^{71}$ Râmiz ve Âdâb-ı Zurafâ'sı 1994: 198'de I. Mahmûd dönemi âlim şairlerinden olduğu belirtilmekte ve Mecmûa'da yer alan cülûsiyesinin son beyti şiirlerine örnek olarak verilmektedir. 


\section{Sonuç}

Yukarıda ayrıntılı olarak açıklandığı ve döküm listesinde de gösterildiği gibi Hıfzî Mecmûası dikkat çekici bir eserdir. Öncelikle kütüphanelerde bulunan benzerlerinin çoğunun aksine kimin tarafından ve hangi tarihte derlendiği bellidir. Bu da bize Hıfzî Ağa'nın şahsında, mecmûaları derleyenler hakkında bazı tespitlerde bulunmamıza imkân tanımaktadır. Hıfzî Ağa’nın devrin devlet memurlarının yetiştirildiği Galata Sarayı'nda başlayan kariyeri Topkapı Sarayı'nda kâtipler zümresine katılmasıyla devam etmiş, nihayetinde "çerağ" edilince zamanın en büyük limanlarından olan İstanbul gümrüğünde görev yapmıştır. Manevi eğitimi için de Emir Buharî Hankahı ile yakın teması olmuş, yine yaşadığı dönemin tanınmış hat üstatlarından meşk etmiştir. Sultan I. Mahmûd'a sunulan şiirlere ulaşabilecek mevkide bulunması da, Mecmûa için yaptığı seçimlerde etkili olmuştur. TSM Arşivinnde bulunan aynı yıllarda I. Mahmûd için yazılmış bazı şiirleri eserine kaydetmeyen Hıfzî̀nin Mecmûa'da şiiri bulunan şairlerin çoğunu kendi yakın çevresinden seçtiği anlaşılmaktadır. Ayrıca Mecmûa'nın ikinci kısmını meydana getiren "Rûznâme" de Patrona Halil İsyanı sırasında İstanbul'da meydana gelen karışıklıklar ve padişahların tahtan indirilip, tahta çıkması konusunda yaşanan olayları yakından takip etme imkânı sunmaktadır. Ruznâme kısmında sayfa kenarlarına düşülen târîhler ise o zaman zarfında yapılan atamaların bir listesi mahiyetindedir. Böylece Hıfzînin Mecmûası kendi eserleri ile birlikte onunla aynı siyasi ve edebî muhite dâhil olan şairlerin şiirlerini bir araya getirmektedir, diyebiliriz. Çünkü çoğunluğu kalemiye mensubu olduğu anlaşılan şairlerin birbiri ile yakın temasta bulundukları anlaşılmaktadır. Mecmûa ile ilgili akla gelen bir soru da padişaha sunulmak üzere yazıldığı anlaşılan eserin, neden onun mührünü taşımadığıdır. Bu sorunun cevabını ulaşmak elimizdeki bilgilerle şimdilik mümkün olmadı. Fakat sır kâtipliği gibi önemli bir görevde bulunmuşken Topkapı Sarayı dışında bir vazifeye atanan Hıfzî Ağa/Hıfzî Mehmed Efendi’nin biyografisi ile ilgili karanlık noktalar aydınlatılabilirse belki bu sorunun cevabına da ulaşılabilir. Mecmûalar üzerinde yapılacak bu tip araştırmalar, klasik şiir ile tarih ilişkisi ve şiirin toplumdaki işlevi bakımından da önemli verilere ulaşmamıza imkân tanıyacaktır. 


\section{Hıfzî Mecmûası'nın (TSMK-Revan 1977) MESTAP'a Göre Şiir Dökümü}

\begin{tabular}{|c|c|c|c|c|c|c|c|}
\hline \multicolumn{2}{|c|}{ Yer Nu } & \multicolumn{6}{|l|}{ TSMK -Revan 1977} \\
\hline 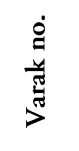 & $\frac{\mathfrak{\pi}}{\sum^{\frac{\pi}{2}}}$ & Matla' beyti & Makta' beyti & 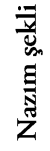 & 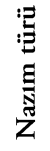 & Vezin & Açıklamalar \\
\hline$\stackrel{\pi}{-}$ & $\frac{4}{2}$ & $\begin{array}{l}\text { Habbezâ tuğrâ-yı garrâ-yı cihân-ârâ k'anın } \\
\text { Cilve-gâhı bahr ü ber ins ü perî fermân-beri }\end{array}$ & $\begin{array}{l}\text { Râm ederse emrine dünyâyı ser-tâ-ser n'ola } \\
\text { Hırz edinmiş nâm-1 Sultân-1 'adâlet-güsteri }\end{array}$ & $\stackrel{\text { N }}{\stackrel{n}{=}}$ & 突 & -..-1-..--1-..-1-..- & $\begin{array}{l}\text { Kıt'a der vasf-1 } \\
\text { tuğrâ-yı garrâ- } \\
\text { y1 Sultân }\end{array}$ \\
\hline 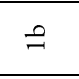 & \multicolumn{7}{|c|}{ 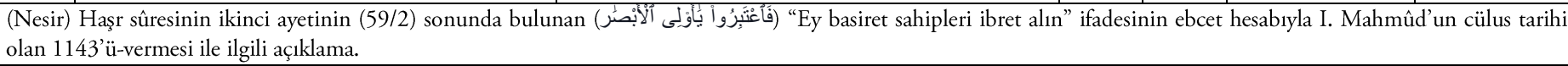 } \\
\hline 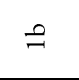 & \multicolumn{7}{|c|}{$\begin{array}{l}\text { (Nesir) "Kutbü'l-arz" terkibinin de ebced hesabıyla I. Mahmûd’un cülûs tarihi olan } 1143 \text { 'ü vermesinin "halîfe-i İslâm” olana padişahın "kutb-1 merkez-i hilâfet" olduğu } \\
\text { hakkındaki açıklama. }\end{array}$} \\
\hline$\stackrel{0}{=}$ & $\frac{4}{2}$ & هبخليفة من كل وجله الانام بفضله & سجلوسه اتاريخ قطمد الينا قداتى & 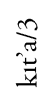 & 㞼 & & \\
\hline 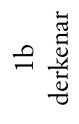 & $\frac{4}{0}$ & هذا ويدلت براحنه قد صفت مشاربه & ومجده حميدة عواقبه دمآم ملكه & 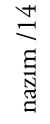 & 丞 & & $\begin{array}{l}\text { Târîh-i } \\
\text { 'Arabî' }\end{array}$ \\
\hline
\end{tabular}

${ }^{72}$ Yazmada kırmızı mürekkeple yazılmış kısımlar italik yazılark gösterilmiştir.

\section{Akademik Dil ve Edebiyat Dergisi}

Cilt/Volume: 3, Sayı/Issue: 4, Aralık/December 2019 


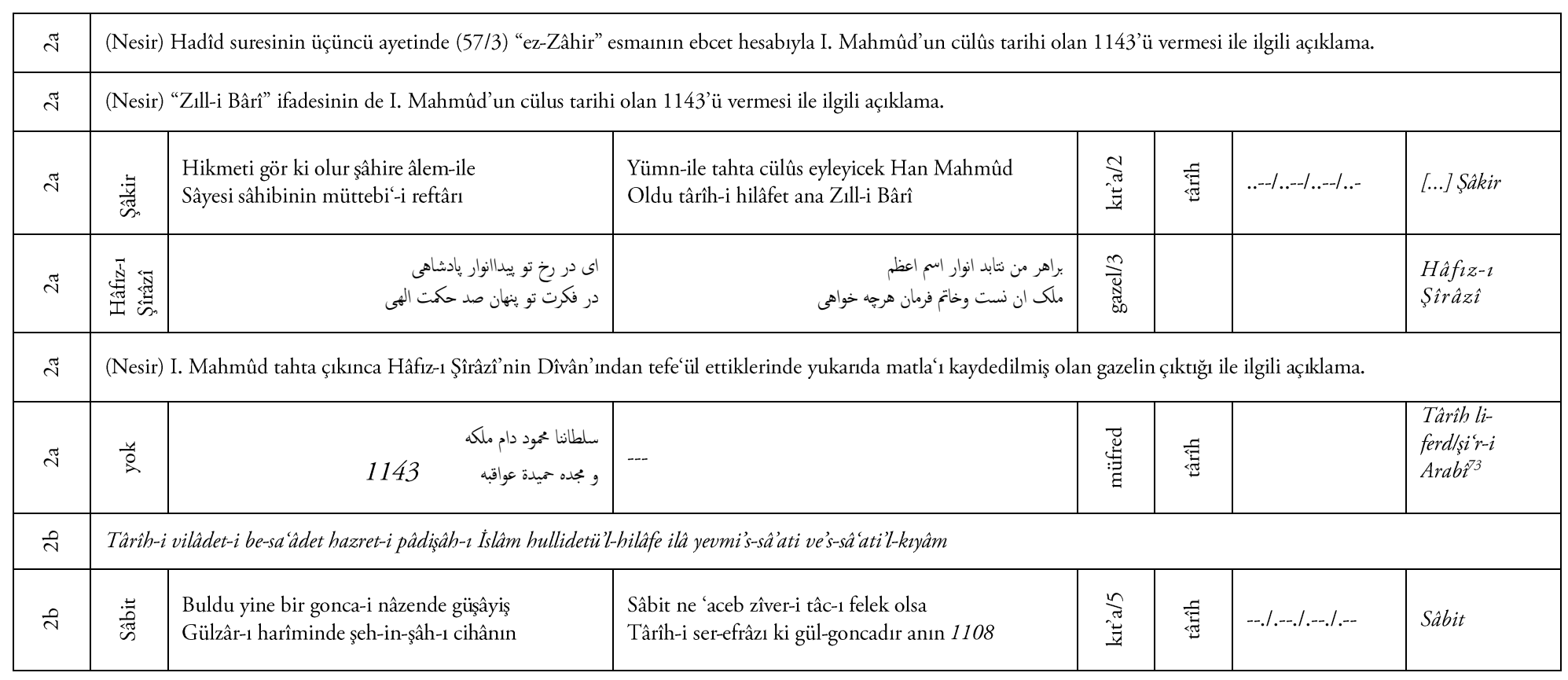

\footnotetext{
${ }^{73} \mathrm{Bu}$ beyit 1b-2a derkenarındaki şiirin târîh mısraıdır.
} 
54| Ustalara Saygı I: Prof. Dr. Fatma Sabiha KUTLAR OĞUZ'a Armă̆an

\begin{tabular}{|c|c|c|c|c|c|c|c|}
\hline$\tilde{n}$ & 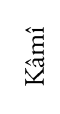 & $\begin{array}{l}\text { Zihî ferhunde-dem Sultân-1 a'zam Mustafâ Ha- } \\
\text { nın } \\
\text { Safâ-bahş oldu bir şeh-zâdesi a'lâ vü ednâya }\end{array}$ & $\begin{array}{l}\text { Bu târîh-i vilâdet toğdu tab'-1 Kâmî-i zâra } \\
\text { Zihî şeh-zâde Mahmûd 'izzetiyle geldi dünyâya } \\
1108\end{array}$ & ñ & 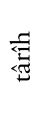 &.$--1 .--1 .--1 .---$ & Kâmî \\
\hline$\pi$ & $\stackrel{\leftrightarrow}{i !}$ & $\begin{array}{l}\text { Bi-hamdillâh sipihr-i sülb-i Sultân Mustafâ } \\
\text { Handa } \\
\text { Meh-i burc-ı necâbet saldı pertev mülk-i îcâda }\end{array}$ & $\begin{array}{l}\text { Ola hıfz-1 İlâhî̀de budur mevlûduna târîh } \\
\text { Velîdü’n-nûr sülb-i Mustafâ Mahmûd şehzâde } \\
1108\end{array}$ & $\underset{-\pi}{\infty}$ & 氶 &.$--1 .--1 .---1 .---$ & Nazm-ı Zülfi \\
\hline$\tilde{n}$ & 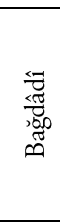 & $\begin{array}{l}\text { Te`âlallâh zihî sultân-1 gâzî zıll-i Rabbânî } \\
\text { Şeh-in-şâh-1 gazanfer-fer dem-âverdir saf-heycâda }\end{array}$ & $\begin{array}{l}\text { Bu lutf-1 bâhirü'l-feyzin nüvîd-i behcet-âsârı } \\
\text { Ferah-bahşâ-yı 'âlem olarak geldikde Bağdâda } \\
\text { Mübârek-bâd edip hHâtif dedi mevlûduna târîh } \\
\text { Gül-i nev-bâr-1 Sultân Mustafâ Mahmûd şehzâde } \\
1108\end{array}$ & 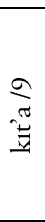 & 茑 &.$--1 .---1 .--1 .--$ & Băgdâdî \\
\hline & \multicolumn{7}{|c|}{ Târih berây-ı ibtidâ-kerden-i ders be-hâce-dâden-i Hazret-i Şehriyâr-ı cihândâr halledallahu mülkehu ilâ yevmi'l-karâr } \\
\hline$\hat{m}$ & $\stackrel{\pi}{\tilde{n}}$ & $\begin{array}{l}\text { Mustafâ Han-1 kerem-kâr-1 şeh-in-şâh-1 cihân } \\
\text { Ki odur mazhar-1 tevfîk-i Hudâvend-i Vedûd }\end{array}$ & $\begin{array}{l}\text { Düşdü yek-pâre bu târîh-i dil-ârâ Sa'dî } \\
\text { Hâceden besmele bed' eyledi Sultân Mahmûd } \\
1113\end{array}$ & $\sum_{\substack{n \\
\frac{\pi}{n}}}^{\infty}$ & 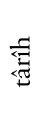 &..$--1 . .--1 . .--1 . .-$ & $S a^{\prime} d \hat{\imath}$ \\
\hline$\hat{n}$ & \multicolumn{7}{|c|}{ Tevârîh-i lihye-nihâden Hazret-i Pâdişâh-ı âlem-penâh dâme lehu'l-izzü'l-câh } \\
\hline$\stackrel{\widetilde{q}}{\mathfrak{y}}$ & 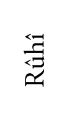 & $\begin{array}{l}\text { Şeh-in-şâh-1 cihân Sultân Mahmûdü'ş-şemâ’il } \\
\text { kim } \\
\text { Hıdivv-i efhamıdır taht-gâh-1 milket-i cûdun }\end{array}$ & $\begin{array}{l}\text { Sitâyiş birle Rûhî eyledim tahrîr târîhin } \\
\text { Cemâlin zîb-i hatt zeyn eyledi Sultân Mahmûdun } \\
1143\end{array}$ & 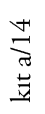 & 远 &.$--1 .--1 .---1 .--$ & $R \hat{u} h \hat{\imath}$ \\
\hline
\end{tabular}

\section{Akademik Dil ve Edebiyat Dergisi}

Cilt/Volume: 3, Sayı/Issue: 4, Arallk/December 2019 


\begin{tabular}{|c|c|c|c|c|c|c|c|}
\hline $\mathscr{f}$ & 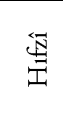 & $\begin{array}{l}\text { Gûş edince dedi âlem bî-bedel târîhini } \\
\text { Hak Teâlâ lihye-i sa'dın mübârek eyleye } \\
1143\end{array}$ & -. & 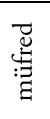 & 胥 & $-. .-1-. .-1-. .-1-.$. & $H i f z \hat{\imath}$ \\
\hline 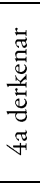 & 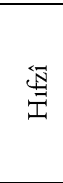 & $\begin{array}{l}\text { Hazret-i pâdişehin Rabb-i Kerîm } \\
\text { Eyleye sâye-i lütfuna memdûd }{ }^{74}\end{array}$ & $\begin{array}{l}\text { Hâme-i Hıfzî kulun târîhin } \\
\text { Bulmaya eyler iken bezl-i vücûd } \\
\text { Kudsiyân dedi felekde yâ Rab } \\
\text { Nûr-1 pâk-bâd hat-1 Sultân Mahmûd } 1143\end{array}$ & $\stackrel{N}{\approx}$ & 胥 &..$--/ . .--/ . .-$ & Diger Hifzî \\
\hline 季 & \multicolumn{7}{|c|}{$\begin{array}{l}\text { Tevârîh-i ma'rûza berây-ı cülûs-ı hümâyûn-ı şevket-makrûn ve tęrrif-kerden-i hazret-i pâdişâh rub'-i meskûn be-serîr-i saltanat-kerden-nümûn ebedallahu } \\
\text { devletuhu'l-emîn }\end{array}$} \\
\hline Fे & 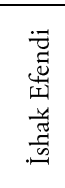 & $\begin{array}{l}\text { Âfâka müjdeler kim bâ-mahz-1 'avn-i ma’bûd } \\
\text { Geçdi serîr-i 'adle şevketlü Han Mahmûd }\end{array}$ & $\begin{array}{l}\text { Târîh içün ederken İshak-1 midhat-âver } \\
\text { Nahv-i hayâl-i nazma sarf-1 nigâh bih-bûd } \\
\text { Hâtif bana o demde târîhini dedi kim } \\
\text { Oldu sarây-1 devlet a'lâ makâm-1 Mahmûd } 1143\end{array}$ & 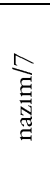 & 急 & $--. /-.--1--. \mid-. .-$ & Ishak Efendi \\
\hline nึ & 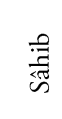 & $\begin{array}{l}\text { Şeh-in-şâh-1 cihân Sultân Mahmûd Han-1 mülk- } \\
\text { ârâ } \\
\text { Çıkınca 'izz ile taht-1 hümâyûn-baht u mes'ûda }\end{array}$ & $\begin{array}{l}\text { Dedi bu bî-bedel misra'la Sâhib sâl-i târîhin } \\
\text { Sa'îd olsun İlâhî saltanat Sultân Mahmûda } \\
1143\end{array}$ & $\underset{n}{\pi}$ & 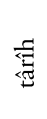 & .---1.---1.---1.--- & Sâhib Efendi \\
\hline กี & 岁 & $\begin{array}{l}\text { Esdi bâd-1 kerem-i Rabb-i Vedûd } \\
\text { Mevc-hîz oldu yine lücce-i cûd }\end{array}$ & $\begin{array}{l}\text { Şükr-i teşrîfi içün kilk-i Münîf } \\
\text { Etdi seccâde-i evrâka sücûd } \\
\text { Dedi tebrîk ederek târîhin } \\
\text { Habbezâ makdem-i Sultân Mahmûd } 1143\end{array}$ & 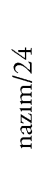 & 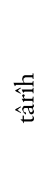 &..$--/ . .--/ . .-$ & Münîf \\
\hline
\end{tabular}

\footnotetext{
${ }^{74}$ Vezni bozuktur.
} 
56 | Ustalara Saygz I: Prof. Dr. Fatma Sabiha KUTLAR OĞUZ’a Armağan

\begin{tabular}{|c|c|c|c|c|c|c|c|}
\hline$\stackrel{n}{n}$ & $\frac{G}{\tilde{Z}}$ & $\begin{array}{l}\text { Hamd ü şükr olsun o Mevlâ-yı 'azîmü'ş-şâna } \\
\text { Ki odur Hakk-ile ser-cümle 'ibâda ma'bûd }\end{array}$ & $\begin{array}{l}\text { Ey Nahîfî bu du'â oldu cülûsa târîh } \\
\text { Ola memdûh-1 Hudâ 'adl-ile Sultân Mahmûd } \\
1143\end{array}$ & 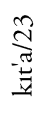 & 劲 & ...--...--/..--/..- & Nahîfi Efendi \\
\hline 8 & 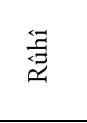 & $\begin{array}{l}\text { Zihî ikbâl-i devlet habbezâ tevfik-i Rabbânî } \\
\text { Ki oldu kevne şâmil feyz-i nâ-ma'dûdu mahdûdu }\end{array}$ & $\begin{array}{l}\text { Bu resme yazdı târîh-i cülûs-1 es'adın Rûhî } \\
\text { Mübârek-bâd tâc-ı Dâver-i Sultân Mahmûdu } \\
1143\end{array}$ & $\underset{\substack{\vec{\sigma} \\
\text { 离 }}}{=}$ & 茎 & 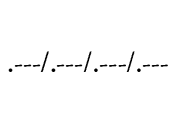 & $R \hat{u} h \hat{\imath}$ \\
\hline$\frac{2}{n}$ & 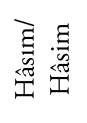 & $\begin{array}{l}\text { Müjdeler fecri tulû́ etdi sabâhü'l-hayrın } \\
\text { Gitdi deycûr-1 şeb-i mazleme oldu nâ-bûd }\end{array}$ & $\begin{array}{l}\text { Hâsım iclâs-1 hümâyûna sezâ bir târîh } \\
\text { Fitne reff oldu cülûs eyledi Sultân Mahmûd } \\
1143\end{array}$ & 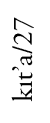 & 苞 & ...--...--/..--/..- & Hâsım/Hâsim \\
\hline$\infty$ & 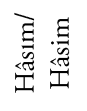 & فلثنة مظلمة دهان شغد خرم & 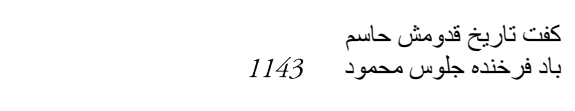 & 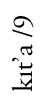 & 荀 & & Diger ve lehu \\
\hline$\infty$ & $\begin{array}{l}\vec{\Delta} \\
\stackrel{\vec{v}}{山}\end{array}$ & $\begin{array}{l}\text { Hazret-i Sultân Mahmûd bin Sultân Mustafâ } \\
\text { Burc-1 esaddan misâl-i âfitâb oldu be-dîd }\end{array}$ & $\begin{array}{l}\text { Düssdü bir târîh ey Feyzî cülûsuna dedim } \\
\text { Han Mahmûdun cülûsu ola dünyâya sa î̀d } \\
1143\end{array}$ & 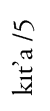 & 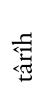 & $-\ldots--\mid-\ldots-\ldots / \ldots .--/ \ldots-$ & Feyzî \\
\hline
\end{tabular}

\section{Akademik Dil ve Edebiyat Dergisi}

Cilt/Volume: 3, Sayı/Issue: 4, Aralı//December 2019 


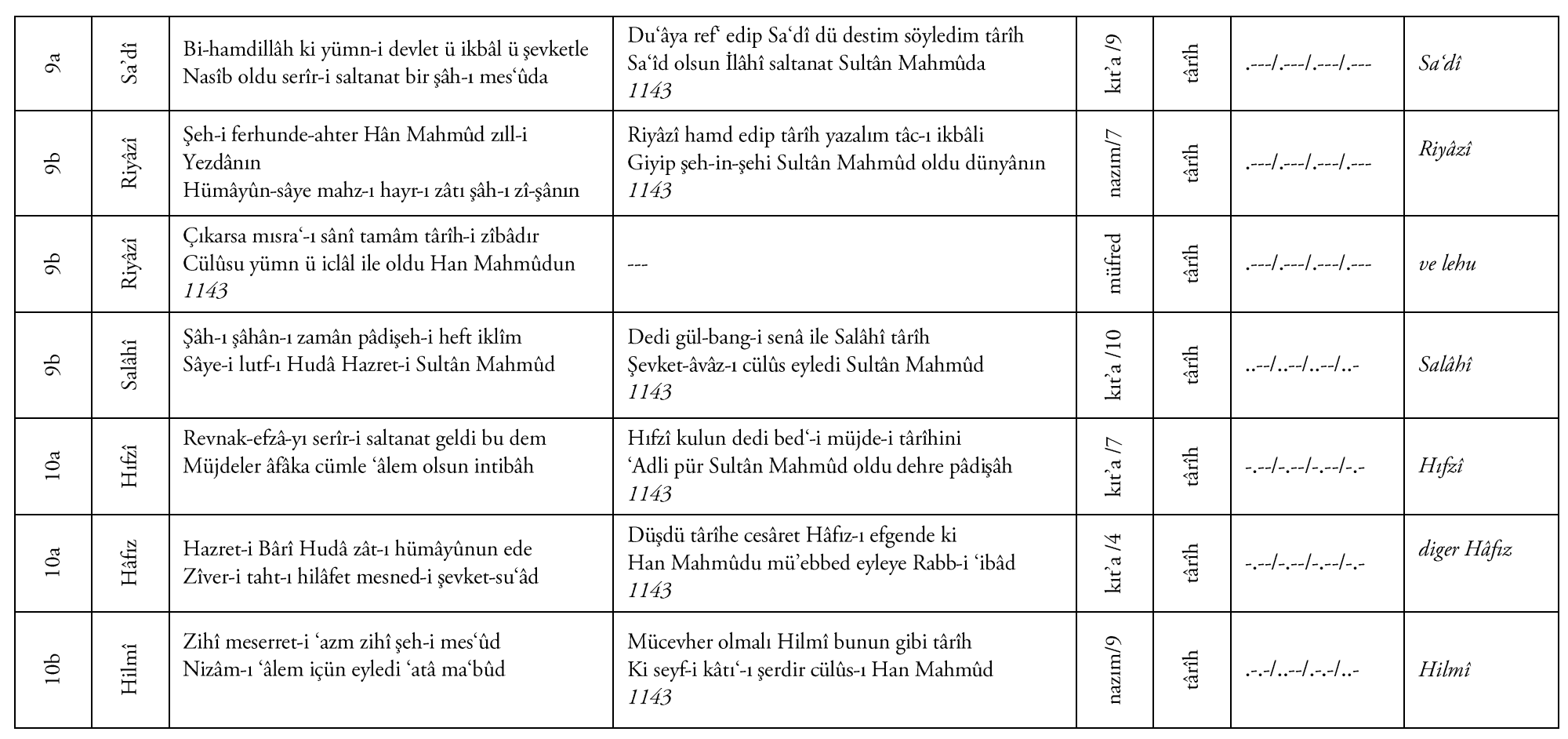




\begin{tabular}{|c|c|c|c|c|c|c|c|}
\hline$\stackrel{0}{0}$ & $\underset{\mathscr{T}}{\mathscr{T}}$ & $\begin{array}{l}\text { Hamdülillâh kudsiyân-ı âsumân eyler nidâ } \\
\text { Saltanatdan Han Mahmûd olmasın bir dem } \\
\text { cüdâ }\end{array}$ & $\begin{array}{l}\text { Eyleyip ikdâm-ı himmetle kıyâm-ı müstedâm } \\
\text { Rûz u şeb da'vât-1 sâfa ey Reşî̀ kıl ibtidâ } \\
\text { Hâme zamm-ı dü-zebânla yazdı târîh-i cülûs } \\
\text { Kevkebin mes' ûd ede Sultân Mahmûdun Hudâ } \\
1143\end{array}$ & 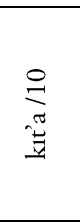 & 胥 & -.--1-..-1-..--|-.- & Reşîd \\
\hline$\stackrel{\Xi}{=}$ & 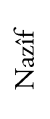 & $\begin{array}{l}\text { Şeh-in-şâh-1 zamâne Hazret-i Sultân Mahmûdun } \\
\text { Fürûğ-1 mihr-i ikbâli cihânı eyledi hurrem }\end{array}$ & $\begin{array}{l}\text { Nazîfâ şevk-ile bir gûne tahrîr eyledim târîh } \\
\text { Cülûs-1 Han Mahmûdla mutayyib oldu hep âlem } \\
1143\end{array}$ & 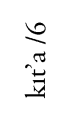 & 丞 & $.--1 .--1 .-\cdots-1 .--$ & $N a z \hat{i} f$ \\
\hline$\underline{\exists}$ & 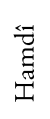 & $\begin{array}{l}\text { Şeh-i şâhân-1 'âlem cenâb-1 Han Mahmûd } \\
\text { Cülûs-1 şevket ile cihânı kıldı pür sûd }\end{array}$ & $\begin{array}{l}\text { Du'â ile dedim Hamdîyâ târîh-i pâkin } \\
\text { Ola ikbâl bâ-Hakk-1 cülûs-1 Han Mahmûd } \\
1143\end{array}$ & 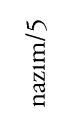 & $\underset{\text { 㤩 }}{ }$ & . - - /....---- & Hamdî \\
\hline$\underline{\exists}$ & 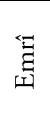 & $\begin{array}{l}\text { Bi-hamdillâh yeniden oldu hâl-i 'âlem âsûde } \\
\text { Müyesser oldu tâc-1 saltanat-1 Sultân Mahmûd }\end{array}$ & $\begin{array}{l}\text { Du'â-yı hayr ile târîhin etdim Emriyâ tahrîr } \\
\text { İlâhî bu cülûsu eyle mes'ûd Han Mahmûda } \\
1143\end{array}$ & $\frac{\sqrt{2}}{\infty}$ & 丞 & .--1.---1.---..-- & Emrî \\
\hline$\stackrel{\text { I }}{(1}$ & $\stackrel{\substack{0 \\
\stackrel{0}{3}}}{\sum}$ & $\begin{array}{l}\text { 'Atâ kıldı Hudâ bir pâdişâh-1 mekremet-kârı } \\
\text { Eder şâhân-1 'âlem dergehinde rûy-fersûde }\end{array}$ & $\begin{array}{l}\text { Mucîbî kıl du'â-yı hayrını yek-pâre bir târîh } \\
\text { Mübârek ola devlet yümn-ile Sultân Mahmûda } \\
1143\end{array}$ & $\stackrel{\pi}{*} \stackrel{n}{=}$ & 丞 & .--1.---1.---1...- & $M u c \hat{b} b \hat{\imath}$ \\
\hline 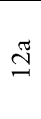 & 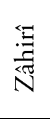 & $\begin{array}{l}\text { Bârekallâh ey şeh-in-şâh-1 cihân-ârâ sana } \\
\text { Bu sipihr-i bî-sütûn olsa sezâdır bâr-gâh }\end{array}$ & $\begin{array}{l}\text { Zâhirî ya çıdıd bir dâ‘î dedi târîhini } \\
\text { Şevk-ile Sultân Mahmûd oldu kevne ya bir şâh } \\
1143\end{array}$ & 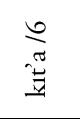 & 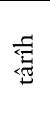 & -.--1-..-1-..-1-..- & Zâhirî \\
\hline సิ & 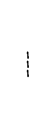 & $\begin{array}{l}\text { Etdi bi-hamdillâh zuhûr lutf-1 Hudâvend-i Gafûr } \\
\text { Gitdi zamân-1 şer ü şûr geldi dem-i şevk ü huzûr }\end{array}$ & $\begin{array}{l}\text { Etdi nidâ nezdîk ü dûr âgâh olun ey ehl-i şûr } \\
\text { Sultân Mahmûd-1 cesûr oldu Hudâvend-i vakûr } \\
1143\end{array}$ & 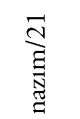 & 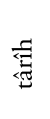 & -..-1--..-1-..-1-...- & -- \\
\hline
\end{tabular}

\section{Akademik Dil ve Edebiyat Dergisi}

Cilt/Volume: 3, Sayı/Issue: 4, Arallk/December 2019 


\begin{tabular}{|c|c|c|c|c|c|c|c|}
\hline 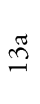 & 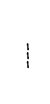 & شز شنشاه جهان سكر حق كم كشت امروز & شمزد دور كفت تاريخ او هاتف سلطان محمود 1143 & $\frac{n}{n}$ & 焉 & & -- \\
\hline$\stackrel{\pi}{\sim}$ & 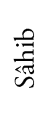 & $\begin{array}{l}\text { Ola memdûh-1 cihân Hazret-i Sultân Mahmûd } \\
\text { Devletin nusretin 'ömrin ile Mevlâ memdûd }\end{array}$ & $\begin{array}{l}\text { Sâhibâ müjde gelip oldu cülûsa târîh } \\
\text { Pâdişâh oldu cülûs etdi o Sultân Mahmûd } \\
1143\end{array}$ & 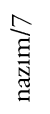 & 志 & ..---/..--/..--/..- & Sâhib \\
\hline กิ & 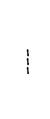 & $\begin{array}{l}\text { Hamdülillâh ki lutf u kerem-i Rabbânî } \\
\text { Buldu ârâyiş-i takdîr-i İlâhîde vücûd }\end{array}$ & $\begin{array}{l}\text { Ber-devâm ola İlâhî dediler târîhin } \\
\text { Şevket-âbâda cülûs eyledi Sultân Mahmûd } \\
1143\end{array}$ & 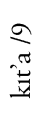 & 胥 & ..--/..--/..--/..- & -- \\
\hline$\stackrel{9}{\unlhd}$ & $\stackrel{x=1}{\pi}$ & $\begin{array}{l}\text { Cenâb-1 Hazret-i Sultân Mahmûd 'izz ü devletle } \\
\text { Cülûs etdi 'adâletle hilâfet tahtına hakkâ }\end{array}$ & $\begin{array}{l}\text { Yazıp harf-i mücevherle Sa'îdâ dediler târîh } \\
\text { Cülûs-1 Han Mahmûd-ile râhat eyledi dünyâ } \\
1143\end{array}$ & $\underset{\substack{\infty \\
\frac{\pi}{n}}}{\infty}$ & 急 & .---|.---|.---|.--.-- & $S a \hat{i} d$ \\
\hline$\stackrel{\Im}{\unlhd}$ & $\stackrel{\Xi}{\Xi}$ & $\begin{array}{l}\text { Hazret-i Sultân Mahmûd dâver-i 'âlem-penâh } \\
\text { Şehr-yâr-1 Cem-haşem Dârâ-şiyem lutf-1 cemîl }\end{array}$ & $\begin{array}{l}\text { Sordum aslın dediler olsun beşâret 'İlmîyâ } \\
\text { Pâdişâh oldu cihâna zübde-i asl-1 asîl } \\
\text { Müjdeler ey ehl-i dil mesrûr olun şimden gerü } \\
\text { Han Mahmûd oldu kevne sâye-i lutf-1 vekîl } \\
1143\end{array}$ & $\stackrel{\infty}{\stackrel{\infty}{=}}$ & 劲 & -.--/-..--..--|-..- & -- \\
\hline$\stackrel{0}{ \pm}$ & $\stackrel{-\Xi}{=}$ & $\begin{array}{l}\text { Çıkdı üçler müjde ile dedi târîh ‘'̇lmiyâ } \\
\text { Hâliyâ Sultân Mahmûd oldu kevne şehriyâr } \\
1143\end{array}$ & -- & 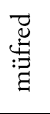 & 急 & -..-1-..-1-..--1-.. & velehu \\
\hline$\stackrel{0}{\ddagger}$ & 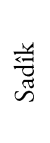 & $\begin{array}{l}\text { Bi-hamdillâh hilâl-i nev zemînde bedr-i mâh } \\
\text { oldu } \\
\text { Ki ya'nî Han Mahmûd mülk-i Osmânîde şâh } \\
\text { oldu }\end{array}$ & $\begin{array}{l}\text { Sadîkâ bî-kesâna müjde edip söyle târîhin } \\
\text { Kerem iklîminin Sultânı Mahmûd pâdişâh oldı } \\
1143\end{array}$ & 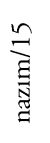 & 㞼 &.$--1 .--1 .---1 .--$ & Sadikk \\
\hline
\end{tabular}


60 | Ustalara Saygı I: Prof. Dr. Fatma Sabiha KUTLAR OĞUZ’a Armăgan

\begin{tabular}{|c|c|c|c|c|c|c|c|}
\hline 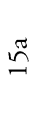 & $\frac{\frac{y}{s}}{\tilde{T}}$ & $\begin{array}{l}\text { Gûye hâtif gûşuma sonra dedi târîh eced } \\
\text { Müjde dehre pâdişâh Sultân Mahmûd şeh ebed } \\
1[1] 43\end{array}$ & -.- & 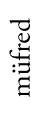 & 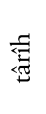 & $-.--|-.--|-.--1 / .$. & velehu \\
\hline$\cong$ & $\frac{y}{\underline{ే}}$ & 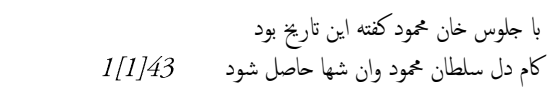 & -.- & 总 & 胥 & & velehu \\
\hline$\cong$ & 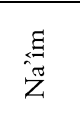 & $\begin{array}{l}\text { Han Mahmûd-ı mu'azzam şâh-ı İskender-zafer } \\
\text { Görse Dârâ 'adl ü dâdın dâmenin eylerdi bûs }\end{array}$ & $\begin{array}{l}\text { Dedi târîhin Na'îmâ geldi gaybdan bir nidâ } \\
\text { Eyledi Sultân Mahmûd Han mevlidde cülûs } \\
1143\end{array}$ & $\stackrel{-\pi}{=}$ & 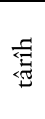 & -.--/-..-|-..--|-.. & $N a^{\prime} \hat{\imath} m$ \\
\hline$\stackrel{0}{\simeq}$ & 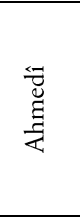 & $\begin{array}{l}\text { Cenâb-1 Han Mahmûd etdi cülûs } \\
\text { Bu gün tahta bi-hamdillâhi'l-Mu'în }\end{array}$ & $\begin{array}{l}\text { Dedi menkût hurûf ile Ahmedî } \\
\text { Anın târîhini bir beytde çünîn } \\
\text { O Mahmûdü'l-hisâli kıldı Celîl } \\
\text { Şeh-i 'âlem imâmün li'l-mü'minîn } \\
1143\end{array}$ & 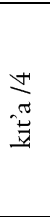 & 运 & .--1.---.-. 75 & -- \\
\hline$\stackrel{\leftrightarrow}{\simeq}$ & 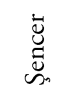 & $\begin{array}{l}\text { Hazret-i Hak Han Mahmûda edip lutf-ı nigâh } \\
\text { 'Arsa-i dehre anı kıldı şeh-i âlem-penâh }\end{array}$ & $\begin{array}{l}\text { Bu cülûsu gûş edip Şencer dedi târîhini } \\
\text { Oldu Mahmûd 'âkıbet nâv-1 zemîne pâdişâh }\end{array}$ & 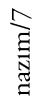 & 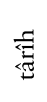 & $-.--1-. .-1-.--1-.-$ & -- \\
\hline$\stackrel{\overparen{0}}{0}$ & 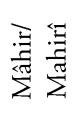 & $\begin{array}{l}\text { Bi-hamdillâh şeref buldu yine mülk-i Süleymânî } \\
\text { Cülûs etdi sa âdet tahtına İskender-i sânî }\end{array}$ & $\begin{array}{l}\text { Te’essüf eder iken Mâhirî hâtif dedi târih } \\
\text { İlâhî Han Mahmûda mü'ebbed ede devrânı } \\
1143\end{array}$ & 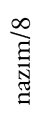 & 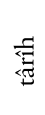 & .---1.---1.---1.-- & -- \\
\hline
\end{tabular}

75 .---/.---/.-- olması gerekir.

\section{Akademik Dil ve Edebiyat Dergisi}

Cilt/Volume: 3, Sayı/Issue: 4, Arallk/December 2019 


\begin{tabular}{|c|c|c|c|c|c|c|c|}
\hline$\stackrel{\overparen{\sigma}}{\sim}$ & 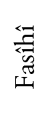 & $\begin{array}{l}\text { Minnet Allaha neşât ile pür oldu âlem } \\
\text { Dest-i tevfîk ile açıldı bu gencîne-i cûd }\end{array}$ & $\begin{array}{l}\text { Sâ'at-i sa'd gelip dedi Fasîhî târîh } \\
\text { Oldu dünyâya şeref makdem-i Sultân Mahmûd } \\
1143\end{array}$ & $\begin{array}{l}\frac{10}{\pi} \\
\frac{\pi}{ \pm}\end{array}$ & 䔍 & ..--/..--/...--/..- & --- \\
\hline ह0 & 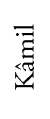 & $\begin{array}{l}\text { Müjde ey ferhunde-baht-1 taht-1 'âlî-menkabet } \\
\text { Âsumân-sâ oldu mikdârun şeh-i devrânla }\end{array}$ & $\begin{array}{l}\text { Geldi bir Kâmil dedi tebşîr edip târîhini } \\
\text { Dîn-i İslâm oldu ihyâ nâm-1 Mahmûd Hanla } \\
1143\end{array}$ & 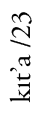 & 莺 & -.--|-...-|-..-|-..- & --- \\
\hline$\stackrel{\pi}{\beth}$ & 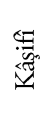 & $\begin{array}{l}\text { Bi-hamdillah cihân mesrûr ü 'âlem şâd-kâm oldu } \\
\text { Sürûr eyyâmı geldi cevri gerdûnun tamâm oldu }\end{array}$ & $\begin{array}{l}\text { Hümâyûn zâtı gibi Kâşifî bir düşdi târîhi } \\
\text { Şeh-in-şâh-ı cihân Sultân Mahmûd hümâm oldı } \\
1143\end{array}$ & 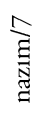 & 胥 & .---1.---1.---1.--- & --- \\
\hline$\stackrel{\pi}{\beth}$ & 猆 & $\begin{array}{l}\text { Hamd ü şükr ü sipâs ü lâ-yuhsâ } \\
\text { Ki nasîb oldu devlet-i 'uzmâ }\end{array}$ & $\begin{array}{l}\text { Beyt-i vâhidde Muhyî anın-çün } \\
\text { İki târîh eyledi inşâa } \\
\text { Oldu Mahmûd Han şeh-i vâlâ }[1] 143 \\
\text { Kıldı şol şer'-i Ahmedi ihyâ }[1] 143\end{array}$ & 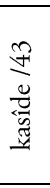 & 胥 &..$--1 .-.-1 . .-$ & --- \\
\hline$\stackrel{0}{\infty}$ & $\stackrel{\Xi}{\breve{G}}$ & $\begin{array}{l}\text { Hamd ola ref oldu zulmet 'âlem oldu müncelî } \\
\text { Şâd ü handân oldu cümle kalmadı hîç tasalı }\end{array}$ & $\begin{array}{l}\text { Şol Rebî‘ü'l-evvelin isneyn gice târihi } \\
\text { Etdi iy Kadrî cülûs Sultân Mahmûd-1 velî } \\
1143\end{array}$ & 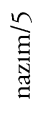 & 㞼 & $-. .-1-. .-1-. .-1-.-$ & Kadrî \\
\hline$\frac{0}{\infty}$ & $\stackrel{5-1}{\sim}$ & $\begin{array}{l}\text { Bi-hamdillah şeref buldu zamâne geldi sultânı } \\
\text { Cülûs etdi henüz sâhib-kerem mün 'im-atâ kânı }\end{array}$ & $\begin{array}{l}\text { Cülûs-1 makdemün meymen görüp Tab'î dedi } \\
\text { târîh } \\
\text { İlâhî Han Mahmûda mü'ebbed ede devrânı } \\
1143\end{array}$ & 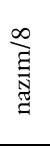 & 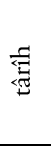 & .--|/.--|.---|.-- & -- \\
\hline
\end{tabular}


62 |Ustalara Saygı I: Prof. Dr. Fatma Sabiha KUTLAR OĞUZ'a Armă̆an

\begin{tabular}{|c|c|c|c|c|c|c|c|}
\hline$\stackrel{\overbrace{}}{\beth}$ & 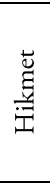 & $\begin{array}{l}\text { Bi-hamdillah sa'âdet tahtın üzre bir münevver } \\
\text { cûd } \\
\text { Tulû' etdi o baht-1 âfitâb-ârây bâ-mes'ûd }\end{array}$ & $\begin{array}{l}\text { Sezâdır lütfuna rahm et bu dầî Hikmet-i nâ-çâr } \\
\text { Der-i lütfunda olsa vaktidir dil nâ’il-i maksûd } \\
\text { Yetişdi himmet-i Kırklarla taht-ı devletin üzre } \\
\text { Cülûs etdi o dem târîhidir Sultân Han Mahmûd }\end{array}$ & ֻ & 丞 & $.--1 .--1, \ldots-1 . \cdots$ & -- \\
\hline$\stackrel{0}{2}$ & $\underset{\substack{\vec{J} \\
>}}{>}$ & $\begin{array}{l}\text { Zîver-i taht-1 şeref-bahş-1 selâtîn-i selef } \\
\text { Dürretü't-tâc-1 şeh-in-şâh-1 'adâlet-meşdûd }\end{array}$ & $\begin{array}{l}\text { Böyle bir târih-i zîbâ çıkıcak tahta dedim } \\
\text { Pâdişâh oldu 'adâlet ile Sultân Mahmûd } \\
1143\end{array}$ & $\sum_{\substack{n \\
\underline{y}}}^{n}$ & 丞 &..$--|. .--| . .--\mid . .-$ & li-Vâhid \\
\hline$\stackrel{2}{2}$ & 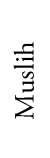 & $\begin{array}{l}\text { Şükr-i Hudâ-yı müste ân } \\
\text { Ki'rdi hayât-1 câvidân }\end{array}$ & $\begin{array}{l}\text { Muslih dedi târîhini } \\
\text { Şâh oldu ol Mahmûd Han } \\
1143\end{array}$ & 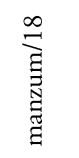 & 丞 & $-. .-1-. .-$ & -- \\
\hline$\stackrel{\sim}{\sim}$ & 胥 & $\begin{array}{l}\text { Fürûğ-1 âfitâb-1 pertev-ârâ-yı zamân tâ kim } \\
\text { Ziyâ-endâz olup bezm-i cihânı eyledi âbâd }\end{array}$ & $\begin{array}{l}\text { Cenâb-1 Hakdan isti' dâ edip 'Âzim dedi târîh } \\
\text { Makâm-1 şâh Sultân Mahmûda sadr hümâyûn-bâd } \\
1143\end{array}$ & 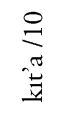 & 芯 & .---1.---1..--1..-- & 'Âzim \\
\hline ᄅ) & $\frac{\vec{\Xi}}{\Xi_{\Sigma}^{\Xi}}$ & $\begin{array}{l}\text { Bârekallah zihî safvet-nümâ behçet me’al } \\
\text { Ahsenallahu zihî ferruh-fezâ ferhunde-fâl }\end{array}$ & 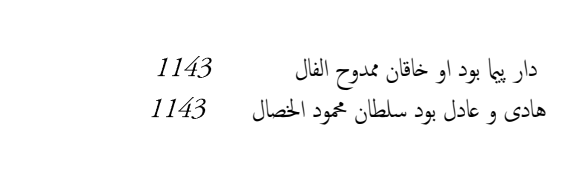 & 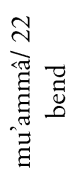 & 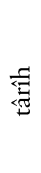 & -.--/_.---_-.--/..- & $\begin{array}{l}\text { Târîh-i } \\
\text { mu'amma- } \\
\text { gûne-i Meh- } \\
\text { med }\end{array}$ \\
\hline
\end{tabular}




\begin{tabular}{|c|c|c|c|c|c|c|c|}
\hline तూ & 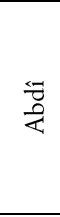 & $\begin{array}{l}\text { Hamdülillah ki bu güne etdi sa âdetle cülûs } \\
\text { Ol meh-i burc-1 hilâfet o hıdivv-i pür cûd }\end{array}$ & $\begin{array}{l}\text { Geldi bir ehl-i senâ 'Abdî hulûs-ile dedi } \\
\text { Harf-i menkût ile bir beytde târîh-i ku'ûd } \\
\text { Hamd-i Hak geldi be-sad 'izz ü hezârân ikbâl } \\
\text { Gülşen-i saltanatın bülbülü Sultân Mahmûd } \\
1143\end{array}$ & $\underset{n}{n}$ & 芯 &..$--/ . .--/ . .--\mid . .-$ & $' A b d \hat{\imath}$ \\
\hline$\underset{\text { ป }}{\pi}$ & $\stackrel{\stackrel{9}{\exists}}{\stackrel{\Xi}{\Xi}}$ & $\begin{array}{l}\text { Kasd-1 ihsân-1 'azîm-ile Hudâ-yı lâ-Yezâl } \\
\text { Gerçi kim gösterdi ehl-i 'asra rûy-1 ihtilâl }\end{array}$ & $\begin{array}{l}\text { Harf-ı cevher-dâr ile Muhlis dedim târîhini } \\
\text { Tahta çıdıd seyf ile Sultân Mahmûdu'l-fi'âl } \\
1143\end{array}$ & 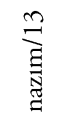 & 胥 & $-.--1-. .-1-. .-1-.-$ & Muhlis \\
\hline तิ & $\stackrel{\stackrel{s}{5}}{5}$ & $\begin{array}{l}\text { Bi-hamdillah ve'l-minne dil-i mahzûnumuz } \\
\text { şimdi } \\
\text { Bütün dünyâ değer bir pâdişâh-ı nükte-dân } \\
\text { buldu }\end{array}$ & $\begin{array}{l}\text { Bu 'abd-i dâ'i-yi 'Ulvî bedîhî dedi târîhin } \\
\text { Cülûs-1 Hân Mahmûd ile dünyâ cümle cân buldu } \\
1143\end{array}$ & 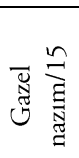 & 胥 & .---/.---|.---|.---- & 'Ulvî \\
\hline ते & \multicolumn{7}{|c|}{ Tevârîh-i ma'rûza berây sene-i cedîde } \\
\hline ते & 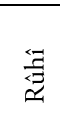 & $\begin{array}{l}\text { Şeh-i Dârâ-haşem Sultân Mahmûd-ı mufahham } \\
\text { kim } \\
\text { Vücûd-ı pâki mazhardır hemîşe lutf-ı ma bûda }\end{array}$ & $\begin{array}{l}\text { Yazıldı Rûhiyâ tebrik-i sâl-i tâze târîhi } \\
\text { Hümâyûn ola sâl-i nev dem-â-dem Han Mahmûda } \\
1144\end{array}$ & $\underset{\rightleftharpoons}{\stackrel{\sigma}{=}}$ & 毒 & .--1.---1.---1.-- & $\begin{array}{l}\text { Târîh berây an } \\
\text { li-muharrirehu } \\
\text { Rûhî }\end{array}$ \\
\hline$\stackrel{\text { ป }}{\stackrel{f}{1}}$ & 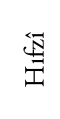 & $\begin{array}{l}\text { Hazret-i Sultân Mahmûdun ki lutf-ı zâtıdır } \\
\text { Matla'-1 nazm-ı selâtîn içre şeh-beyt-i nezîd }\end{array}$ & $\begin{array}{l}\text { Hifzî kulun misra'-i tebrîk-i târîhin dedi } \\
\text { Han Mahmûda mübârek-bâd bu sâl-i cedîd } \\
1144\end{array}$ & 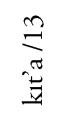 & 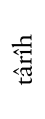 & $-. .-1-. .-1-. .-1-.$. & $H \imath f z \hat{\imath}$ \\
\hline 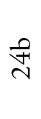 & $\begin{array}{l}\text { 范 } \\
\text { Z }\end{array}$ & $\begin{array}{l}\text { Ey Hudâvend [ü] hıdivv [ü] husrev-i 'âlî-cenâb } \\
\text { Ey şeh-in-şâh-1 cihân sâye-i Rabb-i Mecîd }\end{array}$ & $\begin{array}{l}\text { Mülhemü’l-gayb dedi târîhin du'â-y-ile Nazîf } \\
\text { Han Mahmûda mübârek-bâd bu sâl-i cedîd } \\
1144\end{array}$ & $\underset{n}{n}$ & 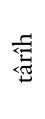 & $-. .-1-. .-1-. .-1-.-$ & $N a z i f f$ \\
\hline
\end{tabular}


$64 \mid$ Ustalara Saygz I: Prof. Dr. Fatma Sabiha KUTLAR OĞUZ’a Armağan

\begin{tabular}{|c|c|c|c|c|c|c|c|}
\hline 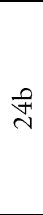 & 馬 & $\begin{array}{l}\text { Habbezâ ey sene-i nev dem-i ferhunde-nümûn } \\
\text { Habbezâ ey ferah-efzâ eser-i sâl-i cedîd }\end{array}$ & $\begin{array}{l}\text { Yeter ey ‘İlmîl-i şeydâ suhen-âverliği koy } \\
\text { Kâbil-i vasf değil mihr-i cihân-tâb-1 ferîd } \\
\text { Dedi bu nev senenin işte budur târîhi } \\
\text { Han Mahmûda bu nev-sâl ola vâlâ-yı sa îd } \\
1144\end{array}$ & $\underset{\substack{n \\
\tilde{n}}}{\stackrel{n}{=}}$ & 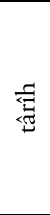 &..$--/ . .--|. .--| . .-$ & $\dot{I} \operatorname{lm} \hat{\imath}$ \\
\hline$\approx$ & 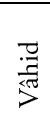 & $\begin{array}{l}\text { Hoşâ ferhunde-sâl-i meymenet-âsâr-1 sa'd-encâm } \\
\text { Bi-hamdillah irişdik böyle hurrem vakt-i } \\
\text { mes' ûda }\end{array}$ & $\begin{array}{l}\text { Hulûl etdikde bin yüz kırk dört sâli dedim târîh } \\
\text { Cedîd sâli sa î̀ eyle Hudâ Sultân Mahmûda } \\
1144\end{array}$ & $\begin{array}{l}N \\
-\frac{\pi}{*}\end{array}$ & 甜 & 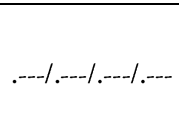 & li-Vâhid \\
\hline$\stackrel{\pi}{\sim}$ & $\frac{\overrightarrow{\bar{y}}}{\mathrm{c}_{\mathrm{s}}}$ & $\begin{array}{l}\text { Bi-hamdillah felek âgâz-1 devr etdi murâd üzre } \\
\text { Göründü mihr-i şâdî günbed-i seb-i şidâd üzre }\end{array}$ & $\begin{array}{l}\text { Suhan pâyâna erdi Şâkirâ hayr-1 duầ eyle } \\
\text { Cenâb-1 Hakka sıldk-ı kalb u ihlâs-1 fu'ầd üzre } \\
\text { Hudâ hem-vâre zâtın mazhar-1 tevfik edip kılsın } \\
\text { Serîr-i saltanatda ferr ü iclâlin ziyâd üzre }\end{array}$ & 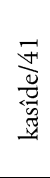 & 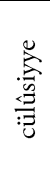 & 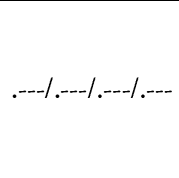 & Şâkir \\
\hline
\end{tabular}

\section{Akademik Dil ve Edebiyat Dergisi}

Cilt/Volume: 3, Sayı/Issue: 4, Aralı//December 2019 


\begin{tabular}{|c|c|c|c|c|c|c|c|}
\hline$\vec{\AA}$ & $\underset{\pi}{\pi}$ & $\begin{array}{l}\text { Bi-hamdillah şeref buldu yine mülk-i cihân ser- } \\
\text { pâ } \\
\text { Cülûs etdi sa âdet tahtına sultân-1 mülk-ârâ } \\
\text { tegazzülün matlac } 1^{76} \\
\text { Ayaklarda kalır la'lîn yanında bâde-i sahbâ } \\
\text { Feminle bahs ederse başa çıkmaz gonca-i hamrâ }\end{array}$ & $\begin{array}{l}\text { Gubâr-1 pây-1 rahş-1 dîde-i gam-dîdene çeken } \\
\text { Sa îdâ tûtiyâ-yı Isfahân-ile olur hem-tâ } \\
\text { Sa îlâ başa çıkmazsın ferâgat et bu da'vâdan } \\
\text { Ne mümkin cümle-i evsâf-1 şâhî eylemek ihsâ } \\
\text { Dem-â-dem şevket ü ikbâl-i tahtın eyleyip müzdâd } \\
\text { Hemîşe kevkeb-i iclâl-i bahtın eylesin iclâ }\end{array}$ & 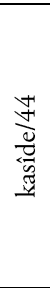 & 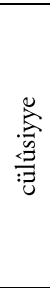 & 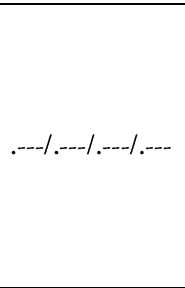 & \\
\hline$\frac{\pi}{m}$ & $\frac{4}{0}$ & $\begin{array}{l}\text { Bârekallah ey sipihr-i devletin sa'd ahteri } \\
\text { Gün gibi kıldın münevver âlem-i bahr ü beri }\end{array}$ & $\begin{array}{l}\text { Tûl-i ‘ömr ile mu'ammer eylesin Bârî Hudâ } \\
\text { Saltanatda ol hıdivv ü dâver-i dîn-perveri }\end{array}$ & $\frac{N}{\frac{N}{g}}$ & 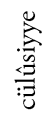 & 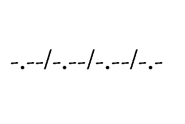 & -- \\
\hline$\vec{m}$ & 燰 & $\begin{array}{l}\text { Tulû́ etdi şeref burcundan ol şems-i cihân-ârâ } \\
\text { Ziyâ vü pertev ü nûr ile toldu cümle-i dünyâ }\end{array}$ & $\begin{array}{l}\text { Kamuya cûd u lutfun erdi ser-tâ-pâ bu âlemde } \\
\text { N'olur Hâkî kulun ahvâline lutf eylesen şâhâ } \\
\text { Ne denlü mihr ü meh tâli' ü gârib ola 'âleme } \\
\text { Füzûn etsin Hudâ ikbâl ü iclâllin kerem-kârâ }\end{array}$ & 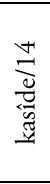 & 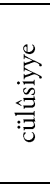 & .---1.---1.---1..-- & -- \\
\hline$\vec{m}$ & $\begin{array}{l}\text { 馬 } \\
\text { 志 }\end{array}$ & $\begin{array}{l}\text { Ey nûr-1 'ayn-1 ma' rifet-i şem'-i cem'-i fazl } \\
\text { Çeşm-i çerâğ-1 cân u dil-i zümre-i fuhûl }\end{array}$ & 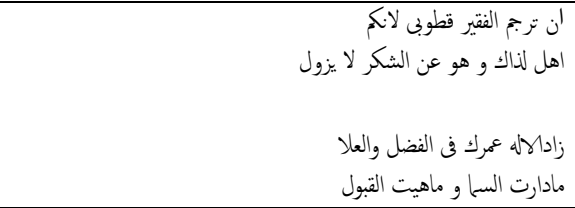 & 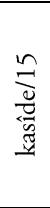 & 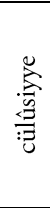 &..$- /-. . . / .-. . /-.$. & $\cdots$ \\
\hline
\end{tabular}

\footnotetext{
${ }^{76}$ Tegazzülün matlaı için derkenara şu not düşülmüş: “Bu kaside ancak bu gazel matla‘nndan ibâret dahi nefsü’l-emr iyi matla‘ idi. Eger sahbâ yerine hamrâ ve hamrâ yerine ra'nâ isti'mâl olunsaydı."
} 


\begin{tabular}{|c|c|c|c|c|c|c|}
\hline तూ & 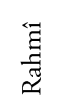 & $\begin{array}{l}\text { Ey kerem kânı vücudun eylesin Hak pâyidâr } \\
\text { Dest-gîr olsun sana ol Hâlık u Perverdigâr }\end{array}$ & $\begin{array}{l}\text { Rahmî-i zârın niyâzı Hazret-i Hakdan budur } \\
\text { Devlet-i dâreyn ile dầim olasın ber-karâr }\end{array}$ & 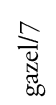 & 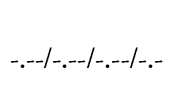 & -- \\
\hline तి & $\frac{\stackrel{n}{3}}{\sum}$ & $\begin{array}{l}\text { Geldi bir mün'im ganî etdi cihânı ni'meti } \\
\text { Halka giydirdi ser-â-ser dürlü dürlü hil'ati }\end{array}$ & $\begin{array}{l}\text { Lâylk oldur kim du'â ede sana bu Muhlis } \\
\text { Bu 'ayândır kim kabûl olur garîbin hâceti } \\
\text { Tahtını Tanrı mübârek eylesin kadrin mezîd } \\
\text { Pâdişâhâ bin yıl olsun 'ömrünün her sâ'ati }\end{array}$ & $\begin{array}{l}\stackrel{n}{\widetilde{U}} \\
\stackrel{\tilde{W}}{\circ}\end{array}$ & -.--/_.--|-..--/..- & --- \\
\hline कृ & $\stackrel{4}{0}$ & $\begin{array}{l}\text { Ey rahîmi rahmeten li'l-ấlemîn } \\
\text { İntihâ-i rahmete olmaz karîn }\end{array}$ & $\begin{array}{l}\text { Mesned-i devletde eyle ber-karâr } \\
\text { Çeşm-i a'dâya ola kec ü gubâr }\end{array}$ & 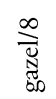 & -..--/...-/..- & -.- \\
\hline 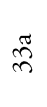 & $\stackrel{4}{0}$ & $\begin{array}{l}\text { Bi-hamdillah şeref buldu yine mülk-i 'Osmânî }{ }^{77} \\
\text { Cülûs etdi sa âdet tahtına İskender-i sânî }\end{array}$ & $\begin{array}{l}\text { Ziyâ-bahş ol rikâbın şu'lesinde gün gibi dâ'im } \\
\text { Semend-i bahtın etsin arsa-i âlemde cevlânı }\end{array}$ & 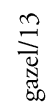 & $.--1 .--1 .-\ldots-1 .---$ & -- \\
\hline
\end{tabular}

${ }^{77}$ Vezni eksik.

\section{Akademik Dil ve Edebiyat Dergisi}

Cilt/Volume: 3, Sayı/Issue: 4, Arallk/December 2019 


\begin{tabular}{|c|c|c|c|c|c|c|c|}
\hline कृ & $\begin{array}{l}\overrightarrow{\mathscr{U}} \\
\stackrel{\Xi}{\Xi} \\
\sum_{\Sigma}^{ \pm}\end{array}$ & $\begin{array}{l}\text { Nev-bahâr erdi bi-hamdillah cihân kesb etdi cân } \\
\text { Zikr-i Hakdan oldu her berg-i çemen ratbü'l- } \\
\text { lisân }\end{array}$ & $\begin{array}{l}\text { Başla Mehemmed du'â-yı devlete âmîn ile } \\
\text { Tutsun âfâkı o dem âvâze-i gird-i beyân } \\
\text { Gecesi Kadr ü Berât ola günü nev-rûz u 'ıyd } \\
\text { Eyle subh-ı haşre dek ''yyş u safâ-yı câvidân }\end{array}$ & 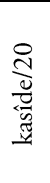 & & -..-1-..--/_..-1/..- & Mehmed \\
\hline$\stackrel{0}{\text { m }}$ & 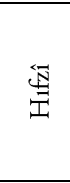 & $\begin{array}{l}\text { Habbezâ dehre ferah-sâz-1 şetâret geldi } \\
\text { Dem-i eyyâm-1 safâ vakt-i meserret geldi }\end{array}$ & $\begin{array}{l}\text { Çekme gam hâlini üftâdelerin bildi o şûh } \\
\text { Hıfziyâ arz-1 niyâz itmeğe ruhsat geldi } \\
\text { Kande iclâl-ile 'azm eylesen istikbâle } \\
\text { Diyeler pâdişehim peyk-i sa'âdet geldi }\end{array}$ & 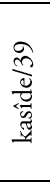 & 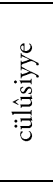 & ..--/...--/..--/..- & $H i f z \hat{\imath}$ \\
\hline$\frac{0}{n}$ & $\stackrel{\vec{\Xi}}{\stackrel{\vec{Z}}{<}}$ & $\begin{array}{l}\text { Ey sa'âdet menba'ı kân-ı kerem sâhib-'atâ } \\
\text { Devlet ü ikbâlini kılsın ebed Bârî Hudâ }\end{array}$ & $\begin{array}{l}\text { Evvelin ü âhirin ma'mûr ola budur ümîd } \\
\text { Hem şefí in ol Resûl mefhar-1 âlem Mustafâ }\end{array}$ & 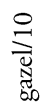 & & $-.--1-. .-1-.--1-.-$ & li-Vâhid \\
\hline 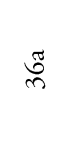 & $\stackrel{s=}{\bar{E}}$ & $\begin{array}{l}\text { Elâ ey pâdişâh-1 zıll-1 ma'bûd } \\
\text { Kapında hâsıl olur cümle maksûd }\end{array}$ & $\begin{array}{l}\text { Bu Şem'î bende ol şeh dergehine } \\
\text { Duâa eyler yüzün sürüp zemîne }\end{array}$ & 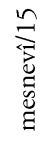 & & .---1.---1.-- & Mesnevî \\
\hline అิ & \multicolumn{7}{|c|}{ Boş } \\
\hline$\frac{\pi}{n}$ & \multicolumn{7}{|c|}{ Boş } \\
\hline$\frac{0}{n}$ & \multicolumn{7}{|c|}{ “İşbu 1143 senesi şehr-i Rebîül-evvelin 15. günü ki yevm-i hâmisdir...” cümlesiyle başlayan ve Patrona Halil İsyanı’nı anlatan mensur Rûznâme (68b’de bitiyor) } \\
\hline
\end{tabular}




\begin{tabular}{|c|c|c|c|c|c|c|c|}
\hline$\stackrel{\substack{\infty \\
\infty}}{\infty}$ & $\stackrel{\bar{z}}{\mathscr{\Xi}}$ & $\begin{array}{l}\text { Rûhiyâ târr̂h-i yek-pâre bu mısra'dan çıkar } \\
\text { Oldu fetvâ-y-ile bârî Mirza-zâde be-kâm }\end{array}$ & -- & 莺 & 节 & 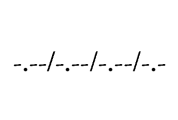 & $\begin{array}{l}\text { Târih-i müftî-şo- } \\
\text { den Mirza-zâde } \\
\text { Efendi }\end{array}$ \\
\hline$\stackrel{\substack{\infty \\
\infty}}{\infty}$ & 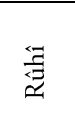 & $\begin{array}{l}\text { Rûhî dü-şakk-1 hâmem târîhin etdi imdâd } \\
\text { Dehre nakîb-i -eşrâf oldu 'İmâd-zâde }\end{array}$ & -- & 莺 & 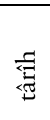 & --..-.-----.-/.-- & $\begin{array}{l}\text { Târîh berây-1 } \\
\text { nekâbet-i ‘'̇mâd- } \\
\text { zâde Efendi }\end{array}$ \\
\hline 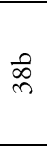 & $\stackrel{\stackrel{\leftrightarrow}{ت}}{\vec{I}}$ & $\begin{array}{l}\text { Gûş edenler dedi târîhini hamd eyleyerek } \\
\text { 'İzz ü şan-1la vezîr oldu Mehemmed Paşa }\end{array}$ & -- & 莺 & 莺 &..$--1 . .--1 . .--1 . .-$ & $\begin{array}{l}\text { Târîh-i Hıfzî } \\
\text { berây-1 vezâret-i } \\
\text { Silâhdâr Mehmed } \\
\text { Paşa }\end{array}$ \\
\hline$\stackrel{\sigma}{\sigma}$ & 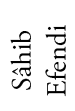 & 5a'dan alınt & & & & & $\begin{array}{l}\text { Tevârîh-i } \\
\text { Cülûsiyye }\end{array}$ \\
\hline के & 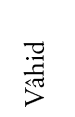 & 19b'den alınt 1 & & & & & \\
\hline$\stackrel{\pi}{\pi}$ & 昰 & 4b'den alınt1 & & & & & \\
\hline ले & 节 & 5a'dan alınt 1 & & & & & \\
\hline
\end{tabular}




\begin{tabular}{|c|c|c|c|c|c|c|c|}
\hline$\stackrel{\sim}{\pi}$ & 竞 & 5b'den alıntı & & & & & \\
\hline$\stackrel{\sim}{\Omega}$ & 运 & 7a'dan alınt1 & & & & & \\
\hline ळూ & 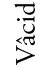 & 8 b'den alınt1 & & & & & \\
\hline$\stackrel{\pi}{n}$ & 节 & 10b'den alınt1 & & & & & \\
\hline$\stackrel{\infty}{n}$ & 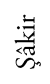 & $\begin{array}{l}\text { Şükr edip yaz sâl-i târîh-i cülûs(1) Şâkirâ } \\
\text { Oldu hakkâ saltanat Sultân Mahmûda makâm }\end{array}$ & -- & 节 & 胥 & - & --. \\
\hline$\stackrel{\sigma}{n}$ & 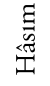 & 7b'den alınt1 & & & & & \\
\hline तु & $\frac{\bar{g}}{\bar{x}}$ & $\begin{array}{l}\text { Çıkardım Rûhiyâ bir mısra'-1 ra'nâda târîhin } \\
\text { Yine Kaplan Geray oldu Kırıma dâver-i emced }\end{array}$ & -- & 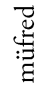 & 胥 & 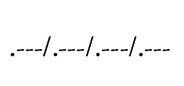 & $\begin{array}{l}\text { Târîh berây Hânî-i } \\
\text { Kaplan Geray Han }\end{array}$ \\
\hline$\underset{\substack{\infty \\
+\infty}}{+1}$ & $\stackrel{\vdots}{\vdots}$ & $\begin{array}{l}\text { Ey Mâlik-i bahr ü ber göster bize dünyâda } \\
\text { Muslîyi musallâda Patronayı deryâda }\end{array}$ & -- & 节 & 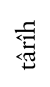 & - & \\
\hline
\end{tabular}


70 | Ustalara Saygz I: Prof. Dr. Fatma Sabiha KUTLAR OĞUZ'a Armağan

\begin{tabular}{|c|c|c|c|c|c|c|c|}
\hline$\underset{\substack{\infty \\
\forall}}{x}$ & $\stackrel{\check{E}}{\check{E}}$ & $\begin{array}{l}\text { Yazıldı Rûhiyâ bir mısra'-1 ra'nâda târîhi } \\
\text { Zihî Sâlim Efendi sadr-1 Anatolı şûd hakka }\end{array}$ & -- & 莺 & 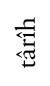 & .---1..--1..--1..--- & -- \\
\hline 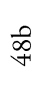 & 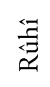 & $\begin{array}{l}\text { Dedim isbât elif ism ile târîhini Rûhî } \\
\text { Sitanbul hâkimi Bû Bekr Efendi-i güzîn oldu }\end{array}$ & -- & 总 & 苞 & .--1.-.-1..--1...- & $\cdots$ \\
\hline$\hat{n}$ & 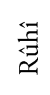 & $\begin{array}{l}\text { Şükr teşrîfiyle Rûhî söyledim târîhini } \\
\text { Âsaf İbrâhîm Paşa oldu sâhib-mühr-i cûd } 1143\end{array}$ & -- & 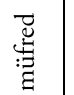 & 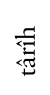 & $-.--|-\ldots--|-\ldots-\ldots / \ldots-$. & Târîh-i Vezâret \\
\hline$\stackrel{\widetilde{\sigma}}{0}$ & 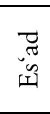 & $\begin{array}{l}\text { Tebâş̂îr-i sabâhü'l-hayr-1 nusret oldu tâbende } \\
\text { Cenâb-1 Hazret-i Hallâka olsun sad senâ vü } \\
\text { hamd }\end{array}$ & $\begin{array}{l}\text { Delîl-i tâli'-i mes' ûdıdur Sultân Mahmûdun } \\
\text { Ki bu feth-i celîlin oldı târîhi gazâ Es'ad } \\
1143\end{array}$ & $\stackrel{\frac{\pi}{y}}{=}=$ & 胥 & .--1.---1.-.--1.--- & $\begin{array}{l}\text { Târîh berây feth-i } \\
\text { cemîl }\end{array}$ \\
\hline ज़े & 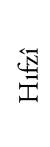 & $\begin{array}{l}\text { Zihî kast-1 şeref-bahşs-1 hümâyûn tarh-1 müstesnâ } \\
\text { Ki seyr-i cân-fezâ-yı âlem-i âb etdirir hakkâ }\end{array}$ & $\begin{array}{l}\text { Dediler kudsiyân tebrîk-i kasra bî-bedel } \\
\text { târîh } \\
\text { Bu nev kasr-1 safâ Sultân Mahmûda } \\
\text { mübârek-câ }\end{array}$ & 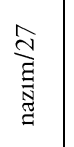 & & 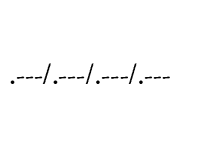 & 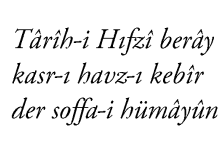 \\
\hline
\end{tabular}

\section{Akademik Dil ve Edebiyat Dergisi}

Cilt/Volume: 3, Sayı/Issue: 4, Aralık/December 2019 


\section{Kaynakça}

Afyoncu, Erhan. (2003). “Osmanlı Siyâsî Tarihinin Ana Kaynakları: Kronikler”. TALİD 1 (2): 101-72.

Afyoncu, Erhan. (2006). Tanzimat Öncesi Osmanlı Tarihi Araştırma Rehberi. İstanbul: Yeditepe Yayınevi.

Aksoyak, İsmail Hakkı. “Tab î, Pîrî Mollası Mustafa Efendi.” http://www.turkedebiyatiisimlersozlugu.com/index.php? sayfa=detay\&detay=3994 [Erișim Tarihi: 25.11.2019]

Arpaemîni-zâde Mustafa Sâmî. (2004). Dîvân. Fatma Sabiha Kutlar. Ankara.

Aypay, A. İrfan. (1992). Nahifî Süleyman Efendi: Hayatı, Eserleri, Edebî Kişiliği ve Divanı'nın Tenkitli Metni. Doktora Tezi. Selçuk Üniversitesi.

Baysun, Cavid. (1954). “Eğrikapılı Rasim Efendi”. IÜEF Tarih Dergisi 7 (10): 1-16.

1730 Patrona İhtilâli Hakkında Bir Eser Abdi Tarihi. (1943). Faik Reşit Unat. Ankara: TTK.

Bosnalı Alaeddin Sabit. (1991). Divan. Sivas: Cumhuriyet Üniversitesi.

Çınar, Şükran. (1974). Patrona Halil İsyanı’na ve Mahmud I Devrine Âit Tarihçe. Bitirme Tezi. İstanbul Üniversitesi.

Doğan, Muhammet Nur Doğan. (1997a) Lâle Devri Şairi Şeyhülislâm Es'ad Efendi ve Divaninın Tenkitli Metni. İstanbul: MEB.

Doğan, Muhammet Nur Doğan. (1997b). Lâle Devri Şairi Şeyhülislâm İshak Efendi Hayâtı, Eserleri ve Divanının Edisyon Kritiği. İstanbul: MEB.

Erişen Yazıcı, Gülgün. (1998). "Edirneli Kâmî ve Divanının Tenkitli Metni. Doktora Tezi. Ankara Üniversitesi.

Erünsal, İsmail E. (2015). Osmanlılarda Kütüphaneler ve Kütüphanecilik, Tarihî Gelişimi ve Organizasyonu. İstanbul: Timaş.

Fatîn Efendi. 1271 [1870]. Tezkire-i Hâtimetü’l-Eşâr. İstanbul: İstihkam Alayları Litografya Destgahı.

Güfta, Hüseyin. (2009). “Sâlim”. TDVİA. c. 36. İstanbul: TDV.

Hâfız Hüseyin Ayvansarâyî. (1985). Mecmuâ-i Tevârih. Fahri Ç. Derin ve Vâhid Çabuk. İstanbul: İÜ Edebiyat Fakültesi.

Hâfız-1 Şîrâzî. (1992). Hafız Divanı. Abdülbaki Gölpınarlı. İstanbul: MEB, 1992. 
Gökalp, Halûk. (2001). Fasîhî Divanı: İnceleme-Metin. Yüksek Lisans Tezi. Çukurova Üniversitesi.

Işık, Ayhan. (2014). “Osmanlı Devleti'nde Nakîbü’l-eşrâflık Müessesesi ve Meşîhat Arşivindeki Nakîbü’l-eşrâf Defterleri”. Alevilik Araştırmaları Dergisi 4, (8): 213-285.

İnan, Göker. (2013). Ahmed Hasîb Efendi'nin Mecmûa-i Tevârîh’i. Yüksek Lisans Tezi. Trakya Üniversitesi.

İpşirli, Mehmed. (2005). "Mirzazâde Şeyh Mehmed Efendi”. TDVİA. c. 30. İstanbul: TDV.

Kançal-Ferrari, Nicole. (2005). Kırım'dan Kalan Miras Hansaray. İstanbul: Klasik.

Kaya, Fazile Eren. "Ulvî, Hüseyin Ulvî Efendi”. http://www.turkedebiyatiisimlersozlugu.com/index.php? sayfa=detay\&detay=6602'de [Erișim Tarihi: 25.11.2019]

Mecmûa. (1143-1144/1730-32). Hıfzî Ağa. Topkapı Sarayı Müzesi Kütüphanesi. Revan 1977.

Mecmûa: Osmanlı Edebiyatının Kırkambarı. (2012). Hatice Aynur vd. İstanbul: Turkuaz.

Mehmed Süreyyâ (1308 [1891]). Sicill-i Osmânî. c.1. İstanbul: Matbaa-i Âmire.

Mehmed Süreyyâ (1311 [1893]). Sicill-i Osmânî. c.2. İstanbul: Matbaa-i Âmire.

Mirzazâde Mehmed Sâlim Efendi. (2018). Tezkiretü’ş-şuarâ. Hazırlayan Adnan İnce. Ankara: e-kitap.

Mîrzâ-zâde Mehmed Sâlim Dîvânı: Tenkitli Basım. (1994). Hazırlayan Adnan İnce. Ankara.

Müstakimzâde. (2011). Tuhfe-i Hattâtîn. Hazırlayan Mustafa Koç. İstanbul: Klasik.

Okumuş, Sait. (2007). Nebzî Divanı: İnceleme Metin. Doktora Tezi. Selçuk Üniversitesi.

Öksüz, Yılmaz. (2010). Eğrikapılı Mehmed Râsim ve Divançesi: İnceleme-Metin. Yüksek Lisans Tezi. Dokuz Eylül Üniversitesi.

Özer, Fatih. (2017). 16. Yüzyıl Türk Edebiyatında Manzum Cülusiyyeler”. Akademik Dil ve Edebiyat Dergisi 1 (1): 1-14.

Pakalın, Mehmet Zeki. (1993). Osmanlı Tarih Deyimleri ve Terimleri Sözlü̈̆̈̈. c. 3. İstanbul: MEB.

Rāmiz ve Ādāb-ı Zurafā’sı. (1994). Hazırlayan Sadık Erdem. Ankara: AKM.

Sarıcaoğlu, Fikret. (2008). "Rûznâme”. TDVİA. c. 35. İstanbul: TDV. 
Şengün, Necdet-Yılmaz Öksüz. (2011). "Şâir Bir Osmanlı Hattatı: Eğrikapılı Mehmed Râsim.” DEÜIFD (34): 77-92.

Toptaş, Emine Sıdıka. "Vâcid". http://www.turkedebiyatiisimlersoz-

lugu.com/index.php?sayfa $=$ detay\&detay $=6200$ 'da [Erișim Tarihi: 25.11.2019]

Türk Dili ve Edebiyatı Ansiklopedisi. (1977-1990). c. 1-7. İstanbul: Dergâh.

Uzun, Mustafa (1995). "Falnâme”. TDVİA. c. 12. İstanbul: TDV.

Uzunçarşıllı, İsmail Hakkı (1988). Osmanlı Devletinin Saray Teşkilatı. Ankara: TTK.

Uzunçarşıll, İsmail Hakkı. (1995). Osmanlı Tarihi. c. 4/2. Ankara: TTK.

Yıldız, Seyhan (2002). XVIII. Yüzyıl Divan Şairi Şâkir: Hayatı, Eseri, Edebî Kişiliği ve Divanının Tenkidli Metni. Yüksek Lisans Tezi. Gazi Üniversitesi.

Yılmaz, Hakan (2018). "Patrona Vak'ası Hakkında Yazılmış Kısa Kronikler ve Devrin Vak'anüvisi Küçük Çelebi-zâde İsmâil ‘Âsım'ın “Tārīhççesi”. Doğu Batı: Metafor ve Gerçeklik Arasında Lâle Devri, 1718-2018 21 (85): 189-191.

Yılmaz, Hakan (2019). "Patrona İsyânı Kronik Yazarlarından 'Abdî ve Destârî Sâlih’in Kimliklerine Işık Tutan İki Önemli Belge”. TAD 38 (66): 245-51.

http://www.ottomaninscriptions.com

http://www.turkedebiyatiisimlersozlugu.com/index.php?sayfa=detay\&detay $=3994$ [Erişim Tarihi: 25.11 .2019$]$

http://kuran.diyanet.gov.tr/mushaf/kuran-meal-2/araf-suresi-7/ayet-43/diyanet-isleri-baskanligi-meali-1 [Erişim 18.11.2019]

MESTAP: https://mestap.com 